\section{Pacific Northwest}

National Laboratory

Operated by Battelle for the

U.S. Department of Energy

\title{
Updated Volumetric Expansion Factors for K Basin Sludge During Storage
}

\author{
A. J. Schmidt \\ C. H. Delegard
}

March 2003

Prepared for the U.S. Department of Energy under Contract DE-AC06-76RL01830 


\title{
DISCLAIMER
}

This report was prepared as an account of work sponsored by an agency of the United States Government. Neither the United States Government nor any agency thereof, nor Battelle Memorial Institute, nor any of their employees, makes any warranty, express or implied, or assumes any legal liability or responsibility for the accuracy, completeness, or usefulness of any information, apparatus, product, or process disclosed, or represents that its use would not infringe privately owned rights. Reference herein to any specific commercial product, process, or service by trade name, trademark, manufacturer, or otherwise does not necessarily constitute or imply its endorsement, recommendation, or favoring by the United States Government or any agency thereof, or Battelle Memorial Institute. The views and opinions of authors expressed herein do not necessarily state or reflect those of the United States Government or any agency thereof.

\author{
PACIFIC NORTHWEST NATIONAL LABORATORY \\ operated by \\ BATTELLE \\ for the \\ UNITED STATES DEPARTMENT OF ENERGY \\ under Contract DE-AC06-76RL01830
}

$\Delta$ This document was printed on recycled paper. 


\title{
Updated Volumetric Expansion Factors for K Basin Sludge During Storage
}

\author{
A. J. Schmidt \\ C. H. Delegard
}

March 2003

Prepared for the U.S. Department of Energy under Contract DE-AC06-76RL01830 and the Hanford Spent Nuclear Fuel Project Managed by Fluor Hanford

Pacific Northwest National Laboratory Richland, Washington 99352 


\section{Summary}

This report provides updated projections of the volumetric expansion resulting from uranium corrosion and gas retention during the containerized storage of Hanford $\mathrm{K}$ Basin sludge. The values provided here supersede (where differences exist) the values provided in Schmidt and Delegard (2002) and Gauglitz and Terrones (2002), as a result of changes made to safety basis physical properties and sludge storage assumptions (Plys and Pearce 2002). This report consolidates all current expansion factor values into a single document, as summarized in Table S.1. These values should be used in design and safety basis calculations. While included here for completeness, the design and safety basis expansion values previously provided for the Large Diameter Container (LDC) storage of K East (KE) floor and KE canister sludge in Pearce (2002) and Plys and Pearce (2002) have not been changed.

K Basin sludge contains metallic uranium and uranium oxides that will corrode, hydrate, and generate gas during containerized storage. From these corrosion reactions, two sludge expansion mechanisms can be expected: 1) expansion of the volume of the sludge solids from the generation of corrosion oxidation products that occupy more space than the starting-state sludge; and 2) expansion of the bulk sludge volume from the retention of hydrogen gas bubbles. Detailed assessments of these two mechanisms were previously made to determine the expected volumetric expansion of the sludge during containerized storage. Schmidt and Delegard (2002) examined the volumetric sludge expansion resulting from uranium corrosion, while Gauglitz and Terrones (2002) estimated the maximum sludge expansion that could occur from gas bubble retention in the KE sludge loaded into an LDC.

This report provides an overview of the methodologies used to calculate sludge expansion from corrosion and gas retention. It also includes a detailed assessment of the expansion resulting from corrosion of $\mathrm{K}$ West (KW) canister sludge that accounts for proposed changes in baseline values for KW canister sludge properties. This report also considers the effects of oxygen on the corrosion chemistry during the storage of the sludge.

In Schmidt and Delegard (2002), the corrosion expansion factors (and related parameters) were calculated for sludge storage both in vented large-diameter [partially oxic (i.e., some oxygen present)] containers and in sealed small-diameter [anoxic (i.e., oxygen-free)] containers. This distinction is important since the presence of oxygen affects the uranium corrosion chemistry. However, during subsequent reviews (Plys and Pearce, 2002, Appendix C), the concept of anoxic corrosion was determined to be nonconservative, since oxygen or other oxidizing species may be generated from radiolysis, resulting in a partially oxic environment, even in a sealed container. Consequently, the updated expansion factor calculation methodology no longer distinguishes between the concept of large-diameter and smalldiameter storage, and the corrosion environment for all containerized sludge storage is now considered to be partially oxic.

Volumetric sludge expansion from corrosion and gas retention will likely occur simultaneously, though at different rates. While the maximum gas retention will occur near the peak gas generation rate (i.e., early in the sludge storage period), it may take years of subsequent uranium compound oxidation to reach the projected end-state uranium compound distribution. However, for design and safety basis calculations, it should be assumed that the maximum expansion from corrosion and gas retention occurs simultaneously. Table S.1 summarizes the overall volume expansion of the sludge streams from volumetric expansion by 
corrosion and gas retention. Table S.1 also includes an estimate of the maximum initial container fill level, assuming that volumetric expansion provides the only constraint on container filling. To maintain the sludge in a saturated state, free water (water above the settled sludge) must be added to the startingstate sludge to provide for both sludge expansion and consumption of water (from corrosion reactions). The free water addition requirements are included in Table S.1.

Table S.1 includes expansion parameters for sludge streams and mixtures of sludge streams. For mixtures, the expansion factors can be calculated by combining the factors from the individual streams on a volume fraction basis. The 40/60 KE canister:floor sludge mixture (i.e., 40 vol $\% \mathrm{KE}$ canister, 60 vol $\%$ KE floor sludge) in Table S.1 represents the safety basis composition of the KE sludge that will be loaded into the LDCs. In the KW Basin, there are two important sludge streams that are composed of mixtures of other streams: the Knock-Out Pot (KOP) sludge and the Settler Tank sludge. The KOP sludge is derived from washing KW and KE fuel elements, and includes fuel piece sludge and canister sludge particles between $500 \mu \mathrm{m}$ and $6350 \mu \mathrm{m}$ ( $0.25 \mathrm{in}$.). A preliminary (and conservative) representation of the KOP sludge has been included in Table S.1 (55/45 fuel piece:KW canister sludge mixture). Fine particles (less than $500 \mu \mathrm{m}$ ) generated from KW and KE fuel washing that are not captured in the KOPs will settle and accumulate in the Settler Tanks. Therefore, it is assumed the Settler Tank sludge will closely resemble size-fractionated KW and KE canister sludge. KW canister sludge can be considered as a conservative representation of the Settler Tank sludge.

Figures S.1 through S.6 illustrate the sludge expansion due to corrosion and gas retention for the sludge types and mixtures stored under partially oxic conditions. These figures are based on the data in Table S.1. Each figure shows the sludge in three stages. In the first stage, one unit volume of sludge at the beginning of containerized storage (starting state) is shown along with the quantity of required free water above the settled sludge. In the second stage, the volume of sludge at the end of containerized storage (end state) is shown, after accounting for expansion by uranium corrosion. At the end state, all free water has been incorporated into the expanded sludge or consumed in the corrosion reactions. For all sludge types evaluated, the volume of the end-state sludge (after corrosion only) is less than the volume of the sum of the starting-state sludge and the initial free water. The third stage shown in Figures S.1 through S.6 is the sludge at maximum expansion from both uranium corrosion and gas retention.

After accounting for both expansion mechanisms, the final volume of fuel piece sludge is 12.9 times the starting-state sludge volume. In comparison, the volume of KE and KW floor sludge increases by a factor of 1.6. The differences in the calculated expansion factors between these two sludge types are the result of significant differences in chemical and physical properties (i.e., total uranium content, uranium metal content, density, and volume fraction water). 


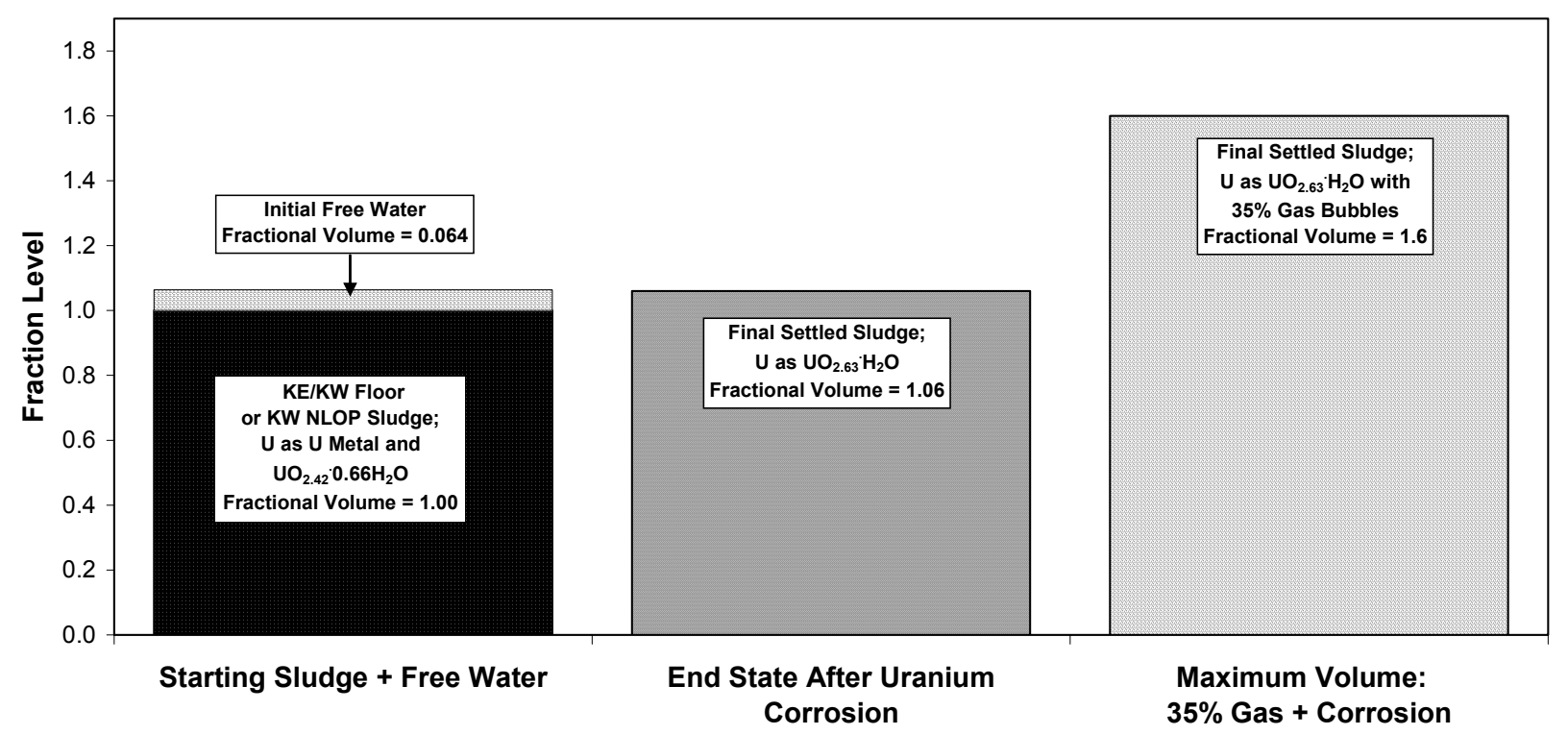

Figure S.1. Volumetric Expansion for KE and KW Floor and KW North Loadout Pit Sludge Due to Expansion from Uranium Corrosion and Gas Retention While Stored Under Partially Oxic Conditions

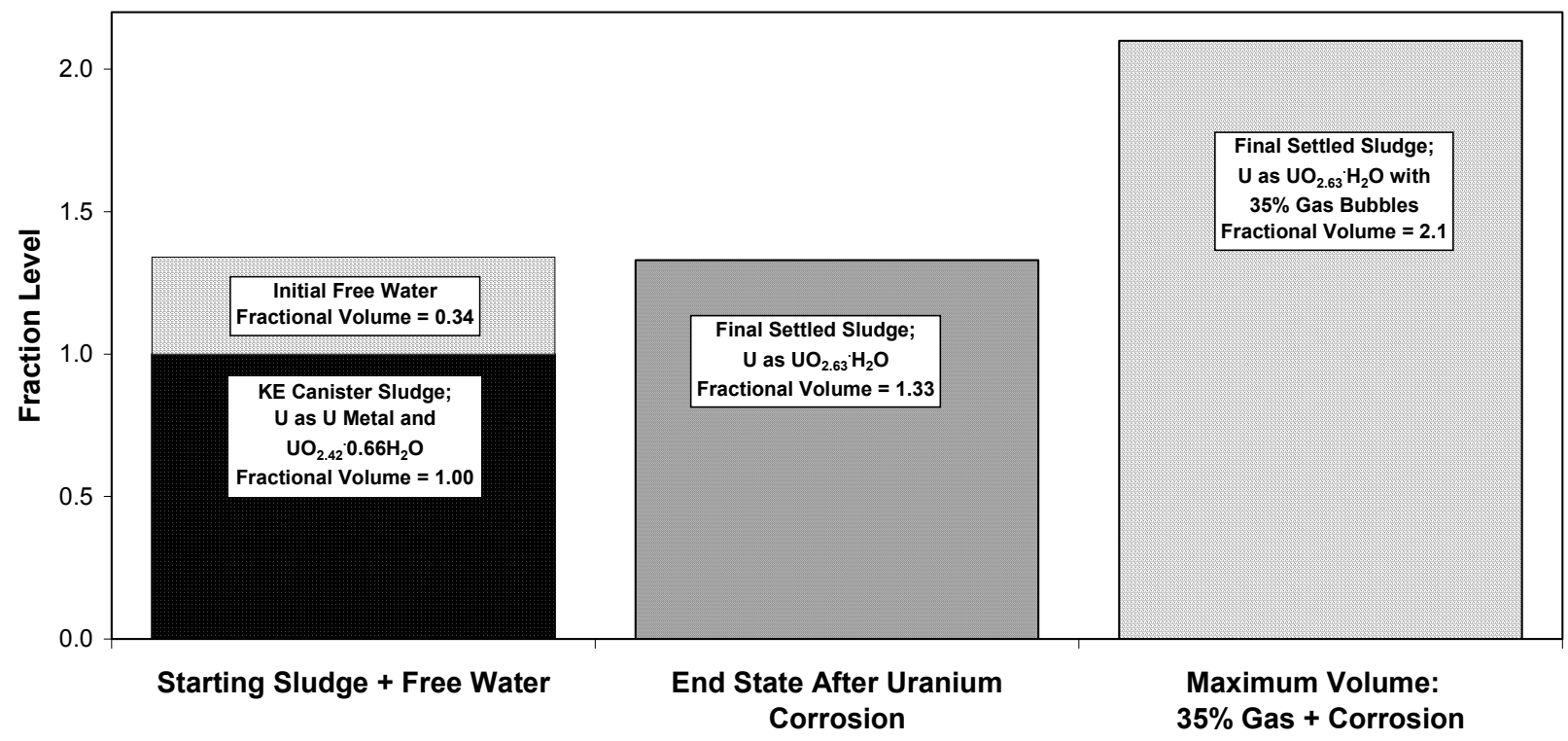

Figure S.2. Volumetric Expansion for KE Canister Sludge Due to Expansion from Uranium Corrosion and Gas Retention While Stored Under Partially Oxic Conditions 


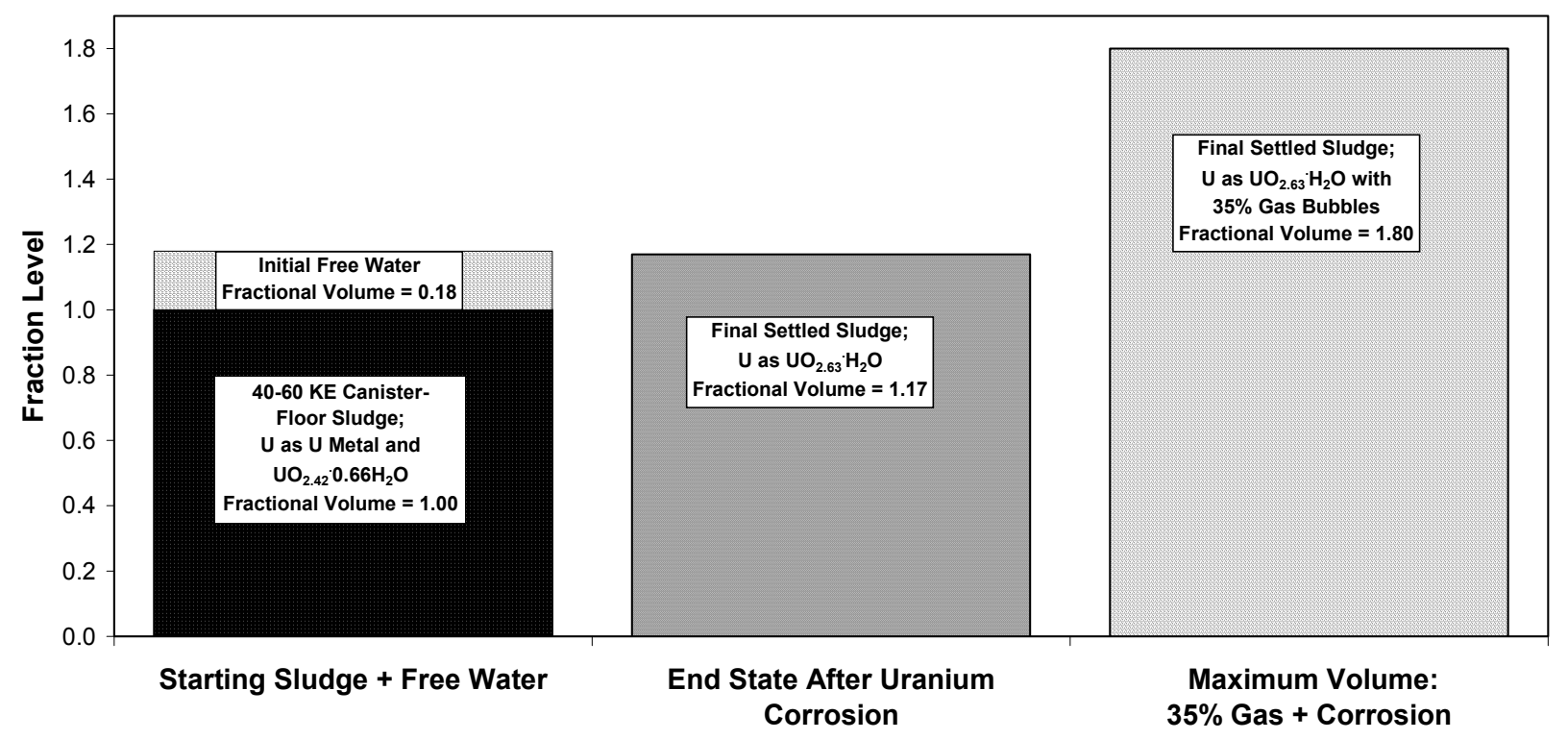

Figure S.3. Volumetric Expansion for a 40/60 KE Canister:KE Floor Sludge Mixture Due to Expansion from Uranium Corrosion and Gas Retention While Stored Under Partially Oxic Conditions

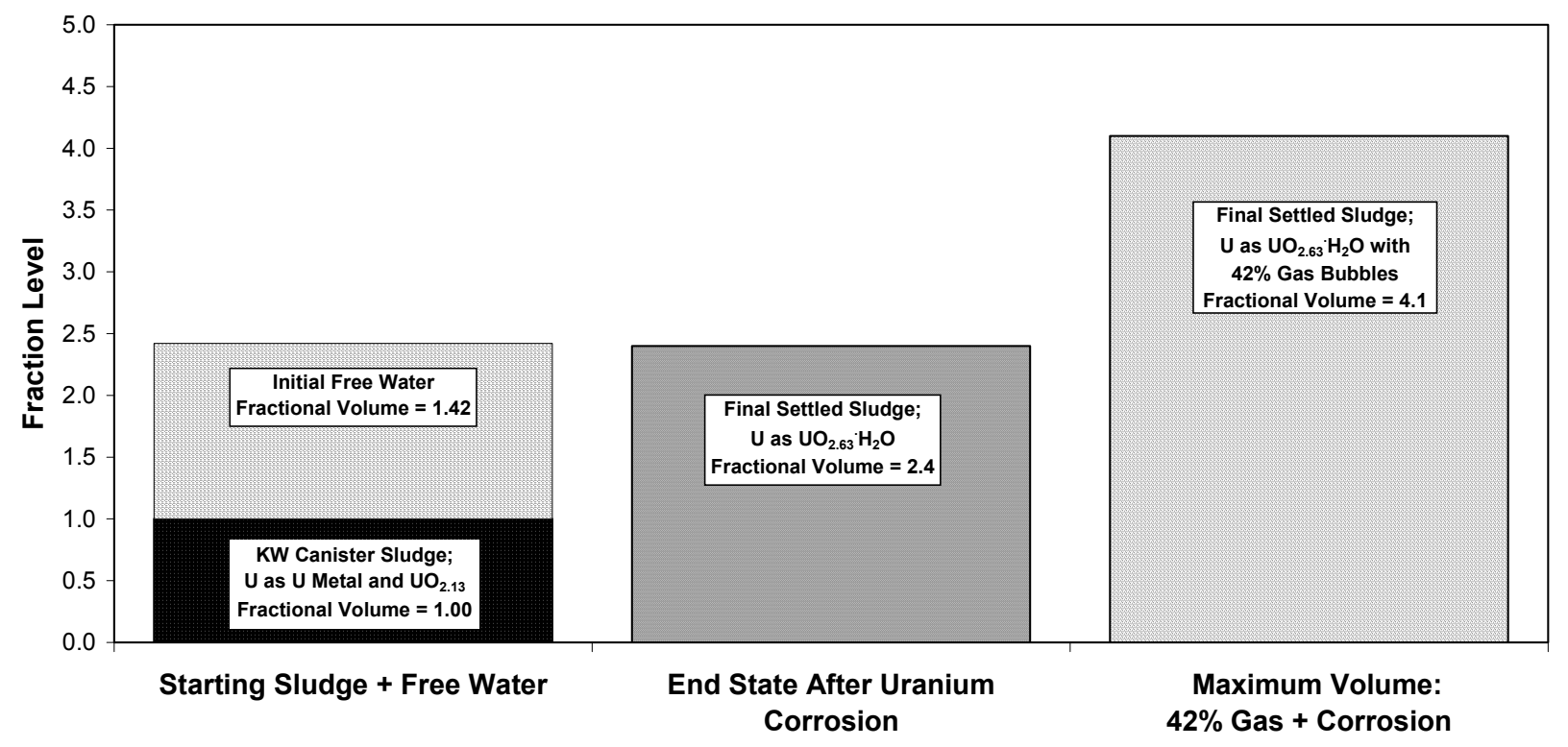

Figure S.4. Volumetric Expansion for KW Canister Sludge Due to Expansion from Uranium Corrosion and Gas Retention While Stored Under Partially Oxic Conditions 


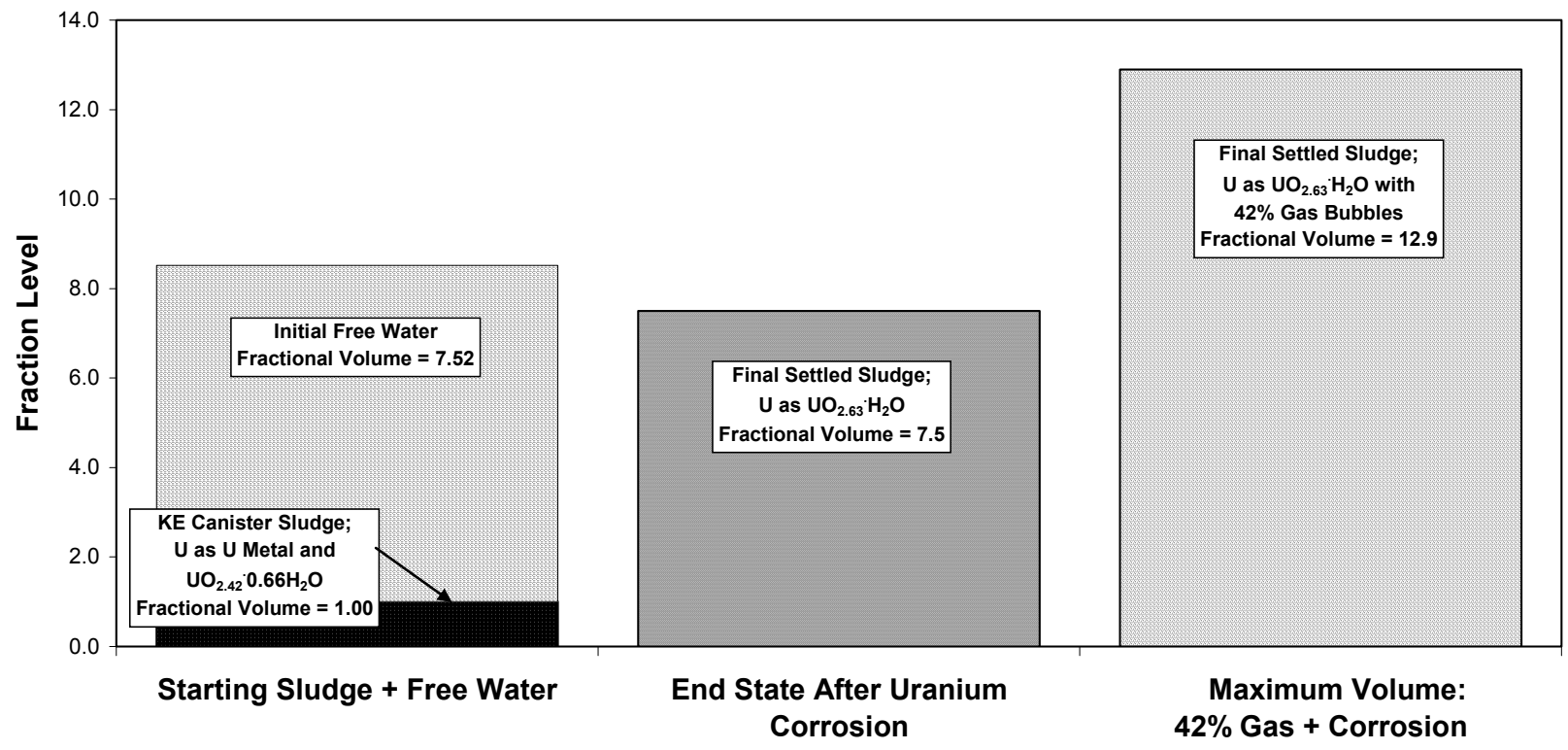

Figure S.5. Volumetric Expansion for Fuel Piece Sludge Due to Expansion from Uranium Corrosion and Gas Retention While Stored Under Partially Oxic Conditions

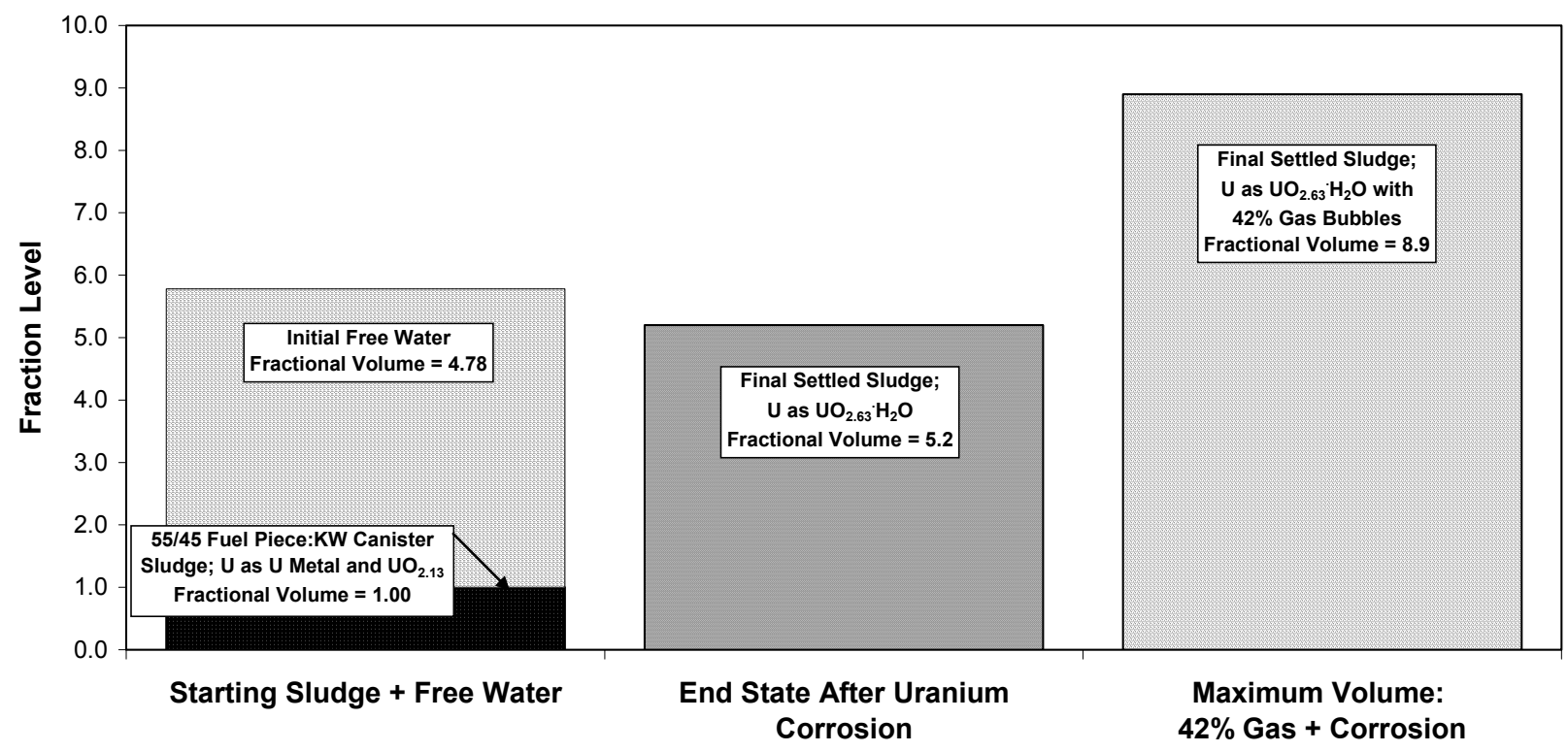

Figure S.6. Volumetric Expansion for a 55/45 Fuel Piece:KW Canister Sludge Mixture Due to Expansion from Uranium Corrosion and Gas Retention While Stored Under Partially Oxic Conditions 


\section{References}

Gauglitz, P. A., and G. Terrones. 2002. Estimated Maximum Gas Retention from Uniformly Dispersed Bubbles in K Basin Sludge Stored in Large Diameter Containers. PNNL-13893, Pacific Northwest National Laboratory, Richland, WA.

Pearce, K. L. 2002. Spent Nuclear Fuel Project Technical Databook, Volume 2, Sludge. HNF-SD-SNF-TI-015, Rev. 9, Vol. 2, Fluor Hanford, Richland, WA.

Plys, M. G., and K. L. Pearce. 2002. Supporting Basis for Spent Nuclear Fuel Project Sludge Technical Databook. SNF-7765, Rev. 1, Fluor Hanford, Richland, WA.

Schmidt, A. J., and C. H. Delegard. 2002. Assessment of K Basin Sludge Volume Expansion Resulting from Uranium Corrosion During Storage. PNNL-13786, Pacific Northwest National Laboratory, Richland, WA. 


\section{Acknowledgments}

The authors gratefully acknowledge and appreciate the technical guidance and programmatic support of Ron Baker and Chris Petersen of Fluor Hanford. We thank Kurt Silvers for his outstanding project management support. We also thank Sue Gano and Brenda Thornton for their diligent editorial and document production support. 


\section{Contents}

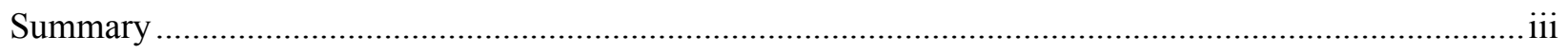

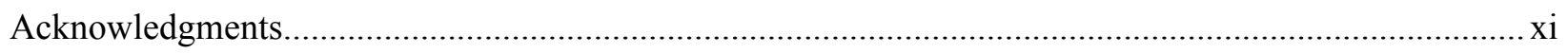

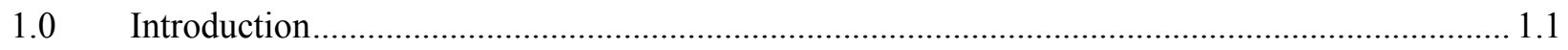

2.0 Sludge Volume Expansion from Uranium Corrosion ........................................................... 2.1

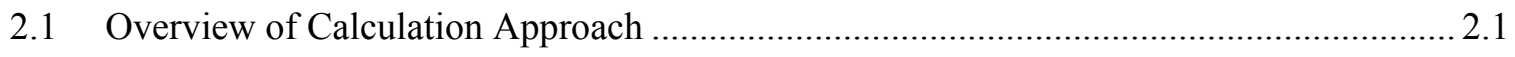

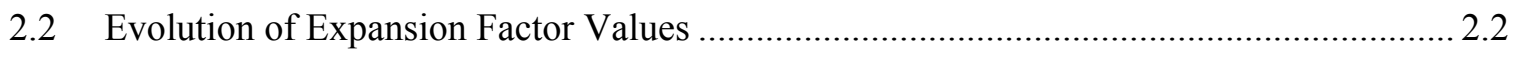

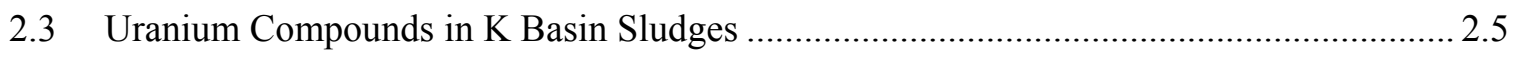

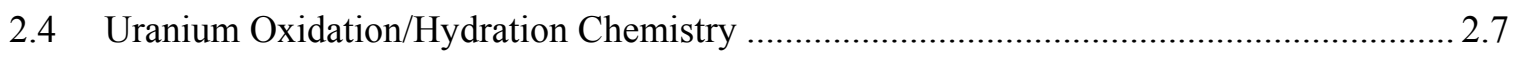

2.5 Assumed Chemistry and End State of Reacted Fuel Pieces ............................................ 2.7

2.6 Assumed Controlling Chemistry of Non-Metallic Uranium Under Partially

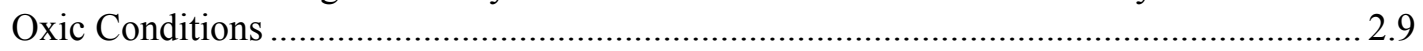

2.6.1 Starting State of Non-Metallic Uranium in K Basin Sludge .............................. 2.9

2.6.2 End State of Non-Metallic Uranium …...................................................... 2.10

2.7 Summary of Corrosion-Based Volumetric Expansion Parameters ................................. 2.10

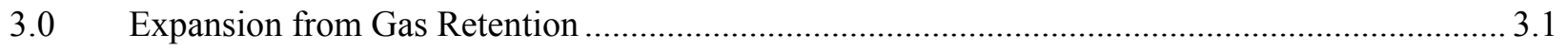

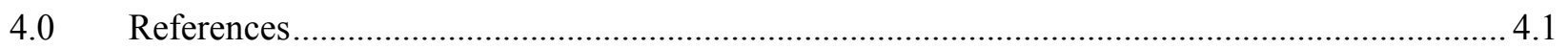

Appendix A Supporting Analysis for Uranium Compound Distribution After 30-Year Storage

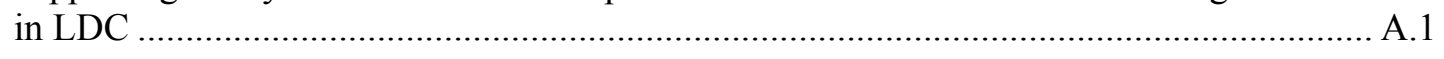

Appendix B Volumetric Expansion of KW Canister Sludge ............................................................. 1 


\section{Figures}

S.1 Volumetric Expansion for KE and KW Floor and KW North Loadout Pit Sludge Due to Expansion from Uranium Corrosion and Gas Retention While Stored Under Partially Oxic Conditions

S.2 Volumetric Expansion for KE Canister Sludge Due to Expansion from Uranium Corrosion and Gas Retention While Stored Under Partially Oxic Conditions ..... vi

S.3 Volumetric Expansion for a 40/60 KE Canister:KE Floor Sludge Mixture Due to Expansion from Uranium Corrosion and Gas Retention While Stored Under Partially Oxic Conditions ...... vii

S.4 Volumetric Expansion for KW Canister Sludge Due to Expansion from Uranium Corrosion and Gas Retention While Stored Under Partially Oxic Conditions ..... vii

S.5 Volumetric Expansion for Fuel Piece Sludge Due to Expansion from Uranium Corrosion and Gas Retention While Stored Under Partially Oxic Conditions . viii

S.6 Volumetric Expansion for a 55/45 Fuel Piece:KW Canister Sludge Mixture Due to Expansion from Uranium Corrosion and Gas Retention While Stored Under Partially Oxic Conditions ..... viii

\section{Tables}

S.1 Summary of K Basin Sludge Expansion Factors Resulting from Uranium Corrosion and Gas Bubble Retention During Storage iv

2.1 Comparison of KE Sludge Input Parameters for Expansion Factor Calculations -

Plys and Pearce (2002) Values and Values Used in Schmidt and Delegard (2002)

2.2 Comparison of KW Sludge Input Parameters for Expansion Factor Calculations -

Updated Values and Values Used in Schmidt and Delegard (2002)

2.3 Fuel Piece Sludge Input Parameters for Expansion Factor Calculations -

Updated Values and Values Used in Schmidt and Delegard (2002) .....

2.4 Particle Densities of Potential and Observed Crystalline Uranium Compounds in K Basin

Sludge

2.5 Total Uranium, Particle Densities, Settled Sludge Densities, and Identified Uranium Phases

for Selected High-Uranium-Content K Basin Sludge Samples and Fuel Fragments...

2.6 Summary of Expansion Factors, Water Consumption, and Initial Container Fill Levels for Containerized K Basin Sludge from Expansion Due to Uranium Corrosion... 


\subsection{Introduction}

At the Hanford K Basins [K East (KE) and K West (KW)], approximately $52 \mathrm{~m}^{3}$ of heterogeneous solid material (sludge), which accumulated during storage of $\mathrm{N}$ Reactor fuel elements, are being packaged, shipped, and stored at T Plant in the Hanford 200 Area until final processing at a future date. This sludge comprises various proportions of fuel; structural corrosion products; windblown material; and miscellaneous constituents, such as ion exchange material (both organic and inorganic) and paint chips (Makenas et al. 1996-99; Pearce 2001). Furthermore, it contains metallic uranium and uranium oxides that will corrode, hydrate, and generate gas during storage. From these corrosion reactions, two sludge expansion mechanisms can be expected: 1) expansion from the generation of corrosion products that are more voluminous than the starting-state sludge; and 2) expansion from the retention of hydrogen gas bubbles within the sludge bed.

Because expansion from corrosion and from gas retention can be concurrent, the impact of these two mechanisms to the sludge volume can be compounding. This report consolidates and updates results of analyses and calculations performed by Pacific Northwest National Laboratory (PNNL) (under contract to the Fluor Hanford Spent Nuclear Fuel Project) to quantify how the various types and sources of K Basin sludge will react and volumetrically expand between the time the sludge is first loaded into the storage containers (starting state) and the time all major volume-changing reactions have been completed (end state). The data from actual $\mathrm{K}$ Basin sludge samples used to support the volumetric sludge expansion analysis were generated in accordance with the Data Objectives for Analysis of Hanford K Basins Sludge to Support Transport to and Storage in T Plant (Makenas 2000) and the Sampling and Analysis Plan for Sludge from 105-K Basins to Support Transport to and Storage in T Plant (Baker et al. 2000).

In this report, updated projections are given for volumetric expansion occurring due to corrosion and gas retention during the containerized storage of $\mathrm{K}$ Basin sludge. Further, this report consolidates all current sludge expansion values into a single document. The updated projections build on previous analyses of sludge expansion [Schmidt and Delegard (2002); Gauglitz and Terrones (2002); and Plys and Pearce (2002)]. Schmidt and Delegard (2002) examined the volumetric sludge expansion resulting from uranium corrosion, while Gauglitz and Terrones (2002) estimated the maximum sludge expansion that could occur from gas bubble retention in the KE sludge loaded into a Large Diameter Container (LDC). The safety basis values for void fraction and total uranium concentration for KE floor and KE canister sludge were updated in Revision 1 of SNF-7765 (Plys and Pearce 2002). Therefore, to maintain consistency, the corrosion expansion values were updated in Plys and Pearce (2002) for the KE sludge streams, using the same chemistry and calculation methodology established in the original evaluation by Schmidt and Delegard (2002), but with the updated safety basis input values. Plys and Pearce (2002) did not update the safety basis parameter values for the KW sludge streams. Therefore, within this report, projections were made for safety basis KW sludge properties. In turn, these properties were used to develop updated sludge expansion factors for KW sludge streams. No changes have been made or proposed to the volumetric expansion factor values for KE floor and KE canister sludge stored in LDCs given in Pearce (2002) and Plys and Pearce (2002).

Section 2.0 of this report presents the approach used to calculate the sludge expansion parameters resulting from corrosion, and describes the rationale for changes made to the original (Schmidt and Delegard 2002) expansion factor values. Data and assumptions on the uranium components in the initial starting-state and end-state sludge are provided, along with the projected uranium corrosion chemistry. The consolidated results of the corrosion-based expansion are also summarized. 
Section 3.0 discusses the bases for the volumetric sludge expansion resulting from the gas bubble retention in $\mathrm{KE}$ and $\mathrm{KW}$ sludges. The rationales for the recommended gas retention value for $\mathrm{KW}$ canister sludge and fuel piece sludge are provided.

Appendix A [taken from Plys and Pearce (2002)] addresses the effects of oxygen from diffusion and from radiolytic decomposition of water on the corrosion chemistry during storage. Supplementary information is provided to support the selection of the end-state uranium compound distribution after all corrosion reactions have taken place during the 30 -year projected sludge storage time.

Appendix B provides detailed volumetric expansion calculations for the partially oxic (with air) corrosion of KW canister sludge. This section illustrates the methodology used to perform the calculations. KW canister sludge was evaluated here, since the volumetric expansion of KW canister sludge under oxic storage conditions was not examined in Schmidt and Delegard (2002). 


\subsection{Sludge Volume Expansion from Uranium Corrosion}

Because the $\mathrm{K}$ Basin sludge contains metallic uranium and chemically reduced uranium oxides that will corrode and hydrate during storage, the end-state corrosion products will result in lower particle densities for uranium-containing compounds and a higher void fraction (volume fraction of sludge occupied by water) than the sludge at the beginning of storage. As the void fraction and particle densities of the uranium-containing compounds change, the volume occupied by a given mass of sludge will also change, resulting in volumetric expansion.

The calculation methodology used in Schmidt and Delegard (2002) is the basis for the calculations given here. The original methodology is summarized in Section 2.1. Section 2.2 describes the basis for the updated expansion values. Section 2.3 summarizes the K Basin sludge data, then provides the basis for the expansion factor analysis. The corrosion chemistries for uranium metal and the non-metallic uranium are presented in Sections 2.4 through 2.6. In Section 2.7, the consolidated results of the corrosion-based expansion are summarized.

\subsection{Overview of Calculation Approach}

For calculating sludge expansion from corrosion, Schmidt and Delegard (2002) assumed that only uranium species continue to oxidize and corrode during storage. All other species, including iron and aluminum corrosion products, zirconium cladding, ion exchange material, wind-blown debris, and sand, were assumed to be inert. For each type of sludge evaluated (fuel fragments, KE canister sludge, KW canister sludge, and KE floor sludge), the safety basis total uranium content was apportioned to specific uranium compounds and metallic uranium to represent the starting-state sludge. The uranium compound assignments were based on K Basin sludge characterization data and the technical literature; the uranium metal assignments were based on safety basis values established in Plys and Pearce (2001). [Note: Plys and Pearce (2002), which includes changes to some safety basis parameters, now supersedes Plys and Pearce (2001).]

Two sludge storage environments were evaluated by Schmidt and Delegard (2002): 1) water-saturated sludge in LDCs stored in air with passive two-way ventilation (oxygen-present or oxic conditions) and 2) water-saturated sludge in small-diameter containers stored underwater with a one-way check valve (oxygen free or anoxic conditions). The distinction of the ventilation was viewed as important, because the presence or absence of oxygen determines the probable chemical reactions and the end-state uranium species. Based on the assumed reaction environment, the corrosion chemistries for metallic and non-metallic uranium were developed (including the quantity of water consumed in the corrosion reactions) and the end-state uranium compounds were determined. The chemistry developed in Schmidt and Delegard (2002) for oxic corrosion assumed limited oxidation and hydration reactions would occur during containerized storage (vs. complete oxidation and hydration). Therefore, this corrosion environment is more appropriately considered partially oxic.

The starting-state and ending-state sludge volume per unit mass was then calculated for each sludge type based on the compound assignments (uranium species and inert fraction), the particle densities of each component, and the void fraction. Next, the sludge corrosion expansion factor was calculated by dividing the end-state sludge volume by the starting-state sludge volume (per unit of initial mass). Schmidt and Delegard (2002) confirmed the expansion factor analysis by comparing the calculated values to actual expansion factor values observed during laboratory testing of $\mathrm{K}$ Basin sludge samples. 
Free water (i.e., water in addition to the interstitial water contained within the starting-state sludge) must be provided with the starting-state sludge to keep the expanding sludge saturated. The ultimate retrieval of containerized sludge is predicated upon keeping the sludge saturated. The quantity of free water required was calculated by performing a water mass balance around the sludge before and after all major volume-changing (and water-consuming) reactions were completed.

The volume of the starting-state sludge plus initial free water was compared with the volume of the ending-state sludge to assess the overall volume change. This comparison assumed that all of the required free water was added at the beginning of containerized storage.

\subsection{Evolution of Expansion Factor Values}

Schmidt and Delegard (2002) calculated corrosion expansion factors (and related parameters) for sludge storage both in large-diameter (partially oxic) containers and in small-diameter (anoxic) containers. However, during subsequent reviews, ${ }^{(a)}$ the concept of anoxic corrosion was determined to be nonconservative, since oxygen or other oxidizing species may be generated from radiolysis, resulting in a partially oxic environment, even in a sealed container. Consequently, the updated expansion factor calculation methodology no longer distinguishes between the concept of large-diameter (partially oxic) and small-diameter (anoxic) storage. The corrosion environment for all containerized sludge storage is now considered to be partially oxic [defined here as corrosion reactions that occur in accordance with the partially oxic corrosion chemistry outlined in Sections 2.4 through 2.6].

The safety basis values for void fraction and total uranium concentration for KE floor and KE canister sludge were updated in Revision 1 of SNF-7765 (Plys and Pearce 2002). Therefore, to maintain consistency, the corrosion expansion values from Schmidt and Delegard (2002) were updated in Plys and Pearce (2002), using the same chemistry and calculation methodology established in Schmidt and Delegard (2002), but with the updated safety basis input values. Table 2.1 compares the KE sludge input values used to establish the corrosion expansion factor parameters in Plys and Pearce (2002) with those previously used by Schmidt and Delegard (2002). The last parameter in Table 2.1, the "expansion factor multiplier," was used to upwardly adjust the calculated expansion factor (and water consumed by chemical reactions) by $50 \%$. This conservative adjustment, based on engineering judgment, was made to account for the uncertainties in the prediction of the void fraction and the starting-state and ending-state uranium compounds.

At the time Plys and Peace (2002) was published, physical property values for a number of KW sludge streams were not defined, and were listed as "to be determined." As a result, KW sludge expansion factor values were not updated within Plys and Pearce (2002). Therefore, one purpose of the current report is to fill in the data gap on KW sludge expansion.

In this report, the KW expansion factors have been updated primarily based on the assumption that the uranium in all containerized sludge will corrode under partially oxic conditions, whereas in Schmidt and Delegard (2002) it was assumed the KW sludge would be stored under anoxic conditions. Table 2.2

(a) Appendix A, originally published in Plys and Pearce (2002), Appendix C, provides a technical basis that shows a truly anoxic environment is unlikely to exist during the projected 30 -year sludge storage period (due to radiolysis of water), even in a container configured with a check valve. 
Table 2.1. Comparison of KE Sludge Input Parameters for Expansion Factor Calculations Plys and Pearce (2002) Values and Values Used in Schmidt and Delegard (2002)

\begin{tabular}{|c|c|c|c|c|}
\hline \multirow[b]{2}{*}{ Parameter } & \multicolumn{2}{|c|}{ KE Floor Sludge } & \multicolumn{2}{|c|}{ KE Canister Sludge } \\
\hline & $\begin{array}{c}\text { Plys and } \\
\text { Pearce (2002) }\end{array}$ & $\begin{array}{l}\text { Schmidt and } \\
\text { Delegard } \\
(\mathbf{2 0 0 2 )}\end{array}$ & $\begin{array}{l}\text { Plys and } \\
\text { Pearce } \\
(2002)\end{array}$ & $\begin{array}{l}\text { Schmidt } \\
\text { and } \\
\text { Delegard } \\
(2002)\end{array}$ \\
\hline Uranium total, $\mathrm{g} / \mathrm{cm}^{3}$ & 0.30 & 0.15 & 1.4 & 1.5 \\
\hline Uranium metal, $\mathrm{g} / \mathrm{cm}^{3}$ & 0.023 & 0.023 & 0.125 & 0.125 \\
\hline Starting settled density, $\mathrm{g} / \mathrm{cm}^{3}$ & 1.5 & 1.5 & 2.5 & 2.7 \\
\hline $\begin{array}{l}\text { Representative non-metallic } \\
\text { uranium in starting state }\end{array}$ & \multicolumn{4}{|c|}{$\begin{array}{c}\text { Same for both analyses, } \mathrm{UO}_{2.42} \cdot 0.66 \mathrm{H}_{2} \mathrm{O} \\
\text { with a particle density of } 7.53\end{array}$} \\
\hline Void fraction, starting state & 0.75 & 0.80 & 0.75 & 0.70 \\
\hline Void fraction, end state & 0.75 & 0.80 & 0.75 & 0.75 \\
\hline $\begin{array}{l}\text { Particle density of non-uranium } \\
\text { solids, }{ }^{\text {(a) }} \mathrm{g} / \mathrm{cm}^{3}\end{array}$ & 1.92 & 3.1 & 2.11 & 3.1 \\
\hline Expansion factor multiplier ${ }^{(b)}$ & 1.5 & 1.0 & 1.5 & 1.0 \\
\hline Reaction pathway & Partially Oxic & Partially Oxic & Partially Oxic & $\begin{array}{c}\text { Partially } \\
\text { Oxic and } \\
\text { Anoxic }\end{array}$ \\
\hline \multicolumn{5}{|c|}{$\begin{array}{l}\text { (a) The non-uranium density is derived from calculations (i.e., not based on direct measurements) and is based } \\
\text { on other assumptions including non-metallic uranium density (i.e., prior to expansion non-metallic uranium } \\
\text { density is assumed to be } 7.53 \mathrm{~g} / \mathrm{cm}^{3} \text { and after expansion, } 6.60 \mathrm{~g} / \mathrm{cm}^{3} \text { ). } \\
\text { (b) The calculated expansion factor and water consumption from chemical reactions are multiplied by this } \\
\text { factor to account for uncertainties in predicting the void fraction and starting-state and end-state uranium } \\
\text { compound distributions. }\end{array}$} \\
\hline
\end{tabular}

compares the KW sludge input values used to establish the corrosion expansion factor parameters in this report with those used by Schmidt and Delegard (2002). Also, to better reflect the corrosion chemistry within the closed KW fuel canisters, a different starting-state uranium oxide compound distribution was assumed for the non-metallic uranium in the KW canister sludge. Because a very conservative set of input parameters have been used for the KW canister sludge (e.g., lower initial void fraction, very high uranium content, and uranium oxides in the starting-state sludge that exhibit a higher particle density), use of an expansion factor multiplier was judged to be unwarranted for this stream. KW floor sludge and KW North Loadout Pit (NLOP) sludge are assumed to be conservatively represented by the KE floor sludge.

Schmidt and Delegard (2002) calculated the volumetric expansion factors for fuel piece sludge stored under partially oxic and anoxic conditions. No changes have been made to the physical property parameters for fuel piece sludge, and as result, the volumetric expansion values in Schmidt and Delegard (2002) for fuel piece sludge under partially oxic conditions have not changed (Table 2.3). The values determined by Schmidt and Delegard (2002) for expansion of fuel piece sludge under anoxic conditions are no longer considered valid for current sludge storage options being considered. Since very conservative input parameters values have been used for fuel piece sludge (very high uranium metal content and a very low initial void fraction), use of an expansion factor multiplier for the fuel piece sludge was judged to be unwarranted. 
Table 2.2. Comparison of KW Sludge Input Parameters for Expansion Factor Calculations Updated Values and Values Used in Schmidt and Delegard (2002)

\begin{tabular}{|c|c|c|c|c|}
\hline \multirow[b]{2}{*}{ Parameter } & \multicolumn{2}{|c|}{$\begin{array}{c}\text { KW Floor, KW NLOP } \\
\text { Sludge }\end{array}$} & \multicolumn{2}{|c|}{ KW Canister Sludge } \\
\hline & $\begin{array}{l}\text { Updated } \\
\text { Values }\end{array}$ & $\begin{array}{l}\text { Schmidt and } \\
\text { Delegard } \\
(2002)\end{array}$ & $\begin{array}{l}\text { Updated } \\
\text { Values }\end{array}$ & $\begin{array}{l}\text { Schmidt and } \\
\text { Delegard } \\
(\mathbf{2 0 0 2})\end{array}$ \\
\hline Uranium total, $\mathrm{g} / \mathrm{cm}^{3}$ & 0.30 & \multirow{10}{*}{$\begin{array}{l}\text { Not } \\
\text { Independently } \\
\text { Considered }\end{array}$} & 2.75 & 2.75 \\
\hline Uranium metal, $\mathrm{g} / \mathrm{cm}^{3}$ & 0.023 & & 0.200 & 0.200 \\
\hline Starting settled density, $\mathrm{g} / \mathrm{cm}^{3}$ & 1.5 & & 4.0 & 4.0 \\
\hline $\begin{array}{l}\text { Representative non-metallic } \\
\text { uranium in starting state }\end{array}$ & $\begin{array}{c}\mathrm{UO}_{2.42} \\
0.66 \mathrm{H}_{2} \mathrm{O}\end{array}$ & & $\mathrm{UO}_{2.13}$ & $\begin{array}{c}\mathrm{UO}_{2.42} \\
0.66 \mathrm{H}_{2} \mathrm{O}\end{array}$ \\
\hline $\begin{array}{l}\text { Particle density of starting-state } \\
\text { non-metallic uranium, } \mathrm{g} / \mathrm{cm}^{3}\end{array}$ & 7.53 & & 11.1 & 7.53 \\
\hline Void fraction, starting state & 0.75 & & 0.65 & 0.70 \\
\hline Void fraction, end state & 0.75 & & 0.75 & 0.75 \\
\hline $\begin{array}{l}\text { Particle density of non-uranium } \\
\text { solids, }{ }^{\text {(a) }} \mathrm{g} / \mathrm{cm}^{3}\end{array}$ & 1.92 & & 3.1 & $\begin{array}{l}\text { no non-U } \\
\text { solids }\end{array}$ \\
\hline Expansion factor multiplier ${ }^{(b)}$ & 1.5 & & 1.0 & 1.0 \\
\hline Corrosion Pathway & Partially Oxic & & Partially Oxic & Anoxic \\
\hline \multicolumn{5}{|c|}{$\begin{array}{l}\text { (a) The non-uranium density is derived from calculations (i.e., not based on direct measurements) and is } \\
\text { based on other assumptions including non-metallic uranium density. } \\
\text { (b) The calculated expansion factor and water consumption from chemical reactions are multiplied by this } \\
\text { factor to account for uncertainties in predicting the void fraction and starting-state and end-state } \\
\text { uranium compound distributions. }\end{array}$} \\
\hline
\end{tabular}

Table 2.3. Fuel Piece Sludge Input Parameters for Expansion Factor Calculations Updated Values and Values Used in Schmidt and Delegard (2002)

\begin{tabular}{|c|c|c|}
\hline \multirow[b]{2}{*}{ Parameter } & \multicolumn{2}{|c|}{ Fuel Piece Sludge } \\
\hline & $\begin{array}{l}\text { Updated } \\
\text { Values }\end{array}$ & $\begin{array}{c}\text { Schmidt and } \\
\text { Delegard (2002) }\end{array}$ \\
\hline Uranium total, $\mathrm{g} / \mathrm{cm}^{3}$ & 9.4 & 9.4 \\
\hline Uranium metal, $\mathrm{g} / \mathrm{cm}^{3}$ & 9.4 & 9.4 \\
\hline Starting settled density, $\mathrm{g} / \mathrm{cm}^{3}$ & 10.5 & 10.5 \\
\hline Void fraction, starting state & 0.4 & 0.4 \\
\hline Void fraction, end state & 0.75 & 0.75 \\
\hline $\begin{array}{l}\text { Particle density of non-uranium } \\
\text { solids, Zircaloy- } 2 \text { cladding, } \mathrm{g} / \mathrm{cm}^{3}\end{array}$ & 6.5 & 6.5 \\
\hline Expansion factor multiplier $^{(a)}$ & 1.0 & 1.0 \\
\hline Corrosion pathway & Partially Oxic & Oxic and Anoxic \\
\hline \multicolumn{3}{|c|}{$\begin{array}{l}\text { (a) The calculated expansion factor and water consumption from chemical } \\
\text { reactions are multiplied by this factor to account for uncertainties in } \\
\text { predicting the void fraction and starting-state and end-state uranium } \\
\text { compound distributions. }\end{array}$} \\
\hline
\end{tabular}




\subsection{Uranium Compounds in K Basin Sludges}

The underlying data and the chemistry used to develop the sludge expansion factors for each sludge type are given here. The chemistry assumptions are derived in part from the K Basin sludge X-ray diffraction (XRD) data. Several limitations are associated with the XRD data that could affect the chemistry assumptions. For example, XRD is semi-quantitative; therefore, the assignments on the masses of the uranium species in the expansion factor evaluation are somewhat speculative. Also, since XRD only detects crystalline compounds, the presence and potential impacts of amorphous materials are unknown. Finally, during the K Basin sludge characterization campaigns, several unknown compounds were consistently detected by XRD. These unknowns could have been additional uranium phases.

Table 2.4 lists most of the uranium phases detected in K Basin sludge samples and provides particle density data. Although known to be present in K Basin sludge, uranium metal was not detected in any of the K Basin sludge samples. During XRD analysis, small portions of the main sample are evaluated in air, and rapid oxidation of the small particle can occur; also, x-rays cannot penetrate surface layers more than a few microns. Therefore, underlying phases, such as $\mathrm{U}$ metal covered by $\mathrm{UO}_{2}$, may go undetected, even though $\mathrm{U}$ metal is known to be present from other analyses.

Table 2.5 includes characterization information (weight fraction uranium, dry particle density, settled density) on selected $\mathrm{K}$ Basin sludge samples that contain high concentrations of uranium. Where data exist, uranium phases detected via XRD are listed.

Table 2.4. Particle Densities of Potential and Observed Crystalline Uranium Compounds in K Basin Sludge (Makenas et al. 1996-1999; Delegard et al. 2000; Pearce 2001)

\begin{tabular}{|l|l|c|}
\hline \multicolumn{1}{|c|}{ Compound } & \multicolumn{1}{c|}{ Chemical Formula } & Theoretical Particle Density, $\mathbf{g} / \mathbf{c m}^{3}$ \\
\hline Uranium Metal & $\mathrm{U}$ & $19.05 \sim 19.0$ \\
\hline Uraninite & $\mathrm{UO}_{2}$ & 10.95 \\
\hline Uraninite & $\mathrm{U}_{4} \mathrm{O}_{9}\left(\mathrm{UO}_{2.25}\right)$ & 11.30 \\
\hline Urante & $\mathrm{U}_{3} \mathrm{O}_{7}$ & 11.32 \\
\hline Triuranium Octoxide & $\mathrm{U}_{3} \mathrm{O}_{8}$ & 8.3 \\
\hline Schoepite & $\mathrm{UO}_{3} \cdot 2.25 \mathrm{H}_{2} \mathrm{O}$ & 4.87 \\
\hline Metaschoepite & $\mathrm{UO}_{3} \cdot 2 \mathrm{H}_{2} \mathrm{O}$ & 4.87 \\
\hline Paraschoepite & $\mathrm{UO}_{2.86} \cdot 1.5 \mathrm{H}_{2} \mathrm{O}$ & $\sim 5$ \\
\hline Studtite & $\mathrm{UO}_{4} \cdot 4 \mathrm{H}_{2} \mathrm{O}$ & 5.15 \\
\hline Uranium Hydride & $\mathrm{UH}_{3}$ & 11.12 \\
\hline Sodium Uranium Hydroxide Hydrate & $\mathrm{Na}_{2}\left(\mathrm{UO}_{2}\right)_{6}(\mathrm{OH})_{14} \cdot 4 \mathrm{H}_{2} \mathrm{O}$ & $\sim 5$ \\
\hline Sodium Uranium Oxide Hydrate & $\mathrm{Na}_{2} \mathrm{U}_{2} \mathrm{O}_{7} \cdot 6 \mathrm{H}_{2} \mathrm{O}$ & $\sim 5$ \\
\hline Calcium Uranate & $\mathrm{CaU}_{6} \mathrm{O}_{19} \cdot 12 \mathrm{H}_{2} \mathrm{O}$ & $\sim 5$ \\
\hline Potassium Uranate & $\mathrm{K}_{2} \mathrm{UO}_{4}$ & $\sim 5$ \\
\hline
\end{tabular}


Table 2.5. Total Uranium, Particle Densities, Settled Sludge Densities, and Identified Uranium Phases for Selected High-Uranium-Content K Basin Sludge Samples and Fuel Fragments

\begin{tabular}{|c|c|c|c|c|}
\hline Sample Name and Description & \begin{tabular}{|c|} 
Total \\
Uranium, \\
wt\%, dry basis
\end{tabular} & \begin{tabular}{|} 
Dry Particle \\
Density, \\
g/cm
\end{tabular} & $\begin{array}{c}\text { As-Settled } \\
\text { Solids Density } \\
(\text { Wet }), \mathbf{g} / \mathrm{cm}^{3}\end{array}$ & $\begin{array}{l}\text { U Crystalline and Other } \\
\text { Phases Identified via XRD }\end{array}$ \\
\hline \multicolumn{5}{|c|}{ KE Canister Sludge, 1996 Sample Campaign (Makenas et al. 1997) } \\
\hline 96-01 & 82 & NM & 2.09 & $\mathrm{UO}_{2}, \mathrm{U}_{4} \mathrm{O}_{9}, \mathrm{U}_{3} \mathrm{O}_{7}$ \\
\hline $\begin{array}{l}\text { 96-04-L (Lower layer of sludge, } \sim 55 \mathrm{wt} \% \text { of whole } \\
\text { sample) }\end{array}$ & 54 & 4.76 & 1.46 & $\mathrm{UO}_{2}, \mathrm{U}_{4} \mathrm{O}_{9}, \mathrm{U}_{3} \mathrm{O}_{7}, \mathrm{UO}_{3} \cdot 2 \mathrm{H}_{2} \mathrm{O}$ \\
\hline $96-05$ & 88 & NM & 2.62 & $\mathrm{UO}_{2}, \mathrm{U}_{4} \mathrm{O}_{9}, \mathrm{U}_{3} \mathrm{O}_{7}, \mathrm{UO}_{3} \cdot 2 \mathrm{H}_{2} \mathrm{O}$ \\
\hline 96-06-M (Middle layer, $20 \mathrm{wt} \%$ of whole sample) & 83 & 6.90 & 1.92 & $\mathrm{UO}_{2}, \mathrm{U}_{4} \mathrm{O}_{9}, \mathrm{U}_{3} \mathrm{O}_{7}, \mathrm{Al}_{2} \mathrm{O}_{3}$ \\
\hline $\begin{array}{l}\text { 96-06-L (Lower layer of sludge, } \sim 52 \mathrm{wt} \% \text { of whole } \\
\text { sample) }\end{array}$ & 84 & 7.88 & 2.99 & $\mathrm{UO}_{2}, \mathrm{U}_{4} \mathrm{O}_{9}, \mathrm{U}_{3} \mathrm{O}_{7}$ \\
\hline 96-13 & 82 & NM & 2.46 & $\mathrm{UO}_{2}, \mathrm{U}_{4} \mathrm{O}_{9}, \mathrm{U}_{3} \mathrm{O}_{7}$ \\
\hline $96-15$ & 81 & NM & 1.84 & $\mathrm{UO}_{2}, \mathrm{U}_{4} \mathrm{O}_{9}, \mathrm{U}_{3} \mathrm{O}_{7}$ \\
\hline \multicolumn{5}{|c|}{ K West Canister Sludge (Makenas et al. 1998) } \\
\hline $\begin{array}{l}\text { 96-21A (particles } 710 \text { to } 6350 \mu \mathrm{m}, 3 \mathrm{vol} \% \text { of total } \\
\text { sample) }\end{array}$ & NM & 14.85 & NM & $\mathrm{U}_{4} \mathrm{O}_{9}, \mathrm{UO}_{3} \cdot 2 \mathrm{H}_{2} \mathrm{O}$, Graphite \\
\hline $\begin{array}{l}\text { 96-21Rec (particles }<710 \mu \mathrm{m}, 97 \text { vol\% of total } \\
\text { sample) }\end{array}$ & 80 & 7.41 & 3.55 to 4.18 & $\mathrm{U}_{4} \mathrm{O}_{9}, \mathrm{UO}_{3} \cdot 2 \mathrm{H}_{2} \mathrm{O}$ \\
\hline $\begin{array}{l}\text { 96-23-6 (particles } 3350 \text { to } 6350 \mu \mathrm{m}, 7 \mathrm{vol} \% \text { of total } \\
\text { sample) }\end{array}$ & NM & 2.26 & NM & $\begin{array}{l}\mathrm{U}_{4} \mathrm{O}_{9}, \mathrm{UO}_{3} \cdot 2 \mathrm{H}_{2} \mathrm{O} \text {, Graphite, } \\
\mathrm{Al}_{2} \mathrm{O}_{3}\end{array}$ \\
\hline $\begin{array}{l}\text { 96-23-A (particles } 710 \text { to } 3350 \mu \mathrm{m}, 13 \mathrm{vol} \% \text { of total } \\
\text { sample) }\end{array}$ & NM & 2.72 & NM & Mostly Graphite, $\mathrm{U}_{4} \mathrm{O}_{9}, \mathrm{Al}_{2} \mathrm{O}_{3}$ \\
\hline $\begin{array}{l}\text { 96-23Rec (particles }<710 \mu \mathrm{m}, 80 \mathrm{vol} \% \text { of total } \\
\text { sample) }\end{array}$ & 68 & NM & 2.67 & $\begin{array}{l}\mathrm{UO}_{2}, \mathrm{UH}_{3}, \text { Graphite } \\
\mathrm{UO}_{3} \cdot 2 \mathrm{H}_{2} \mathrm{O}, \mathrm{Al}_{2} \mathrm{O}_{3}\end{array}$ \\
\hline $\begin{array}{l}\text { 96-24-6 (particles } 3350 \text { to } 6350 \mu \mathrm{m}, 13 \mathrm{vol} \% \text { of total } \\
\text { sample) }\end{array}$ & NM & 2.54 & NM & $\begin{array}{l}\text { Mostly Graphite, } \mathrm{U}_{4} \mathrm{O}_{9} \\
\mathrm{FeO}(\mathrm{OH})\end{array}$ \\
\hline $\begin{array}{l}\text { 96-24-A (particles } 710 \text { to } 3350 \mu \mathrm{m}, 3 \mathrm{vol} \% \text { of total } \\
\text { sample) }\end{array}$ & NM & 4.71 & NM & $\begin{array}{l}\text { Graphite, } \mathrm{U}_{4} \mathrm{O}_{9}, \mathrm{UO}_{3} \cdot 2 \mathrm{H}_{2} \mathrm{O} \\
\mathrm{Na}_{2} \mathrm{U}_{2} \mathrm{O}_{7} \cdot 2 \mathrm{H}_{2} \mathrm{O}, \mathrm{FeO}(\mathrm{OH}) \\
\mathrm{FeFe}_{2} \mathrm{O}_{4}\end{array}$ \\
\hline $\begin{array}{l}\text { 96-24Rec (particles }<710 \mu \mathrm{m}, 84 \mathrm{vol} \% \text { of total } \\
\text { sample) }\end{array}$ & 54 & 8.11 & 2.64 & $\begin{array}{l}\mathrm{U}_{4} \mathrm{O}_{9}, \mathrm{UO}_{2.86} \cdot 1.5 \mathrm{H}_{2} \mathrm{O} \\
\mathrm{FeO}(\mathrm{OH}), \mathrm{FeFe}_{2} \mathrm{O}_{4}, \mathrm{SiO}_{2}\end{array}$ \\
\hline $96-16$ & 81 & NM & 3.83 & NM \\
\hline \begin{tabular}{|l|}
$96-17$ \\
\end{tabular} & 94 & NM & 3.56 & NM \\
\hline \multicolumn{5}{|c|}{ Residual Sludge (Dislodged from fuel elements during shipping from Basins) (Makenas et al. 1999) } \\
\hline R1-Rec (particles $<250 \mu \mathrm{m}, 51.3 \mathrm{wt} \%$ of total sample) & 68 & 7.16 & NM & $\mathrm{U}_{4} \mathrm{O}_{9}, \mathrm{UO}_{3} \cdot 2 \mathrm{H}_{2} \mathrm{O}$ \\
\hline R5-Rec (particles $<500 \mu \mathrm{m}, 100 \mathrm{wt} \%$ of total sample) & 63 & 7.46 & NM & $\mathrm{U}_{4} \mathrm{O}_{9}, \mathrm{UO}_{3} \cdot 2 \mathrm{H}_{2} \mathrm{O}$ \\
\hline \multicolumn{5}{|c|}{ KE Consolidated Sludges (Bredt et al. 1999; Delegard et al. 2000; Elmore et al. 2000) } \\
\hline $\begin{array}{l}\text { KC-2/3 M250 (KE canister sludge composite particles } \\
<250 \mu \mathrm{m}, \sim 75 \mathrm{wt} \% \text { of sample) }\end{array}$ & 68 & 7.57 & 2.13 & NM \\
\hline $\begin{array}{l}\text { KC-2/3 (250 to } 500 \mu \mathrm{m} \text { particles, } \sim 16 \mathrm{wt} \% \text { of total } \\
\text { sample) }\end{array}$ & NM & 6.91 & NM & NM \\
\hline $\begin{array}{l}\text { KC-2/3 P250 (KE canister sludge particles } 250 \mu \mathrm{m} \text { to } \\
6350 \mu \mathrm{m}, \sim 25 \mathrm{wt} \% \text { of sample }\end{array}$ & 35.2 & $2.23-6.91$ & 2.11 & $\mathrm{U}_{4} \mathrm{O}_{9}, \mathrm{UO}_{3} 2 \mathrm{H}_{2} \mathrm{O}, \mathrm{Al}_{2} \mathrm{O}_{3}$ \\
\hline $\begin{array}{l}\text { KC-5 M250 (KE floor sludge particles }<250 \mu \mathrm{m}, 40 \\
\text { to } 60 \mathrm{wt} \% \text { of sample) }\end{array}$ & 6.4 & 3.14 & 1.19 & NM \\
\hline \multicolumn{5}{|c|}{ Gas Generation III Fuel Fragments ${ }^{(a)}$} \\
\hline $\begin{array}{l}\text { SNF Mid } 80 \text { (particles }<500 \mu \mathrm{m} \text { created by reacting } \\
500 \text { to } 2000 \mu \mathrm{m} \text { uranium metal fragments to point of } \\
\text { no hydrogen generation) }\end{array}$ & $\sim 100$ & 9.4 & 2.8 & $\mathrm{U}_{4} \mathrm{O}_{9}, \mathrm{UO}_{2}$ \\
\hline $\begin{array}{l}\text { SNF M500 (particles }<250 \mu \mathrm{m} \text { after reacting } 0 \text { to } \\
500 \mu \mathrm{m} \text { uranium fuel fragments to the point of no } \\
\text { further hydrogen generation) }\end{array}$ & $\sim 100$ & 8.9 & 2.5 & $\mathrm{U}_{4} \mathrm{O}_{9}, \mathrm{UO}_{2}, \mathrm{UO}_{3} \cdot 2 \mathrm{H}_{2} \mathrm{O}$ \\
\hline \multicolumn{5}{|l|}{$\mathrm{NM}=$ not measured. } \\
\hline \multicolumn{5}{|c|}{$\begin{array}{l}\text { (a) Silvers, K. L. August 3, 2001. "Preliminary Results from Gas Generation Series III Testing." Letter to W. W. Rutherford, Fluor } \\
\text { Hanford. 43610-L01, Pacific Northwest National Laboratory, Richland, Washington. }\end{array}$} \\
\hline
\end{tabular}




\subsection{Uranium Oxidation/Hydration Chemistry}

Oxidation of uranium metal $\left[\mathrm{U}_{(\mathrm{metal})}\right]$ occurs most rapidly in water by direct anoxic reaction with water to form $\mathrm{UO}_{2}$ and, at completion, $\mathrm{UO}_{2.25}$, as shown in Reactions 1 and 2:

$$
\begin{gathered}
\mathrm{U}_{\text {(metal) }}+2 \mathrm{H}_{2} \mathrm{O} \rightarrow \mathrm{UO}_{2}+2 \mathrm{H}_{2} \\
\mathrm{U}_{\text {(metal) }}+2.25 \mathrm{H}_{2} \mathrm{O} \rightarrow \mathrm{UO}_{2.25}+2.25 \mathrm{H}_{2}
\end{gathered}
$$

Thus, it is postulated that the $\mathrm{UO}_{2}$, from Reaction 1, would undergo further oxidation, as shown in Reaction 3:

$$
\mathrm{UO}_{2}+0.25 \mathrm{H}_{2} \mathrm{O} \rightarrow \mathrm{UO}_{2.25}+0.25 \mathrm{H}_{2}
$$

Oxidation beyond $\mathrm{UO}_{2.25}$ requires oxygen to form schoepites $\left(\mathrm{UO}_{2.86} \cdot 1.5 \mathrm{H}_{2} \mathrm{O} ; \mathrm{UO}_{3} \cdot 2 \mathrm{H}_{2} \mathrm{O}\right)$, as shown in Reactions 4 and 5:

$$
\begin{gathered}
\mathrm{UO}_{2.25}+0.305 \mathrm{O}_{2}+1.5 \mathrm{H}_{2} \mathrm{O} \rightarrow \mathrm{UO}_{2.86} \cdot 1.5 \mathrm{H}_{2} \mathrm{O} \\
\mathrm{UO}_{2.25}+0.375 \mathrm{O}_{2}+2 \mathrm{H}_{2} \mathrm{O} \rightarrow \mathrm{UO}_{3} \cdot 2 \mathrm{H}_{2} \mathrm{O}
\end{gathered}
$$

The schoepites can undergo subsequent reactions to form other U(VI) phases. For example, a paragenetic sequence of mineralization is observed in an aerated reaction of unirradiated $\mathrm{UO}_{2}$ with simulated groundwater at $90^{\circ} \mathrm{C}$ (Wronkiewicz et al. 1996; note, the simulated groundwater used in the Wronkiewicz study is higher in dissolved minerals than the ion exchange-purified $\mathrm{K}$ Basin waters). In their study, the $\mathrm{UO}_{2}$, in the form of a pressed and sintered fuel pellet, was observed to transform to $\mathrm{UO}_{2.25}$ and then to schoepite $\left(\mathrm{UO}_{3} \cdot 2 \mathrm{H}_{2} \mathrm{O} ; \rho=4.80 \mathrm{~g} / \mathrm{cm}^{3} ; 322.1 \mathrm{~g} / \mathrm{mole}\right)$, becquerelite $\left(\mathrm{CaU}_{6} \mathrm{O}_{19} \cdot 11 \mathrm{H}_{2} \mathrm{O} ; \rho=5.14 \mathrm{~g} / \mathrm{cm}^{3}\right.$; $1970.4 \mathrm{~g} / \mathrm{mole}$ ), and compreignacite $\left[\mathrm{K}_{2}\left(\mathrm{UO}_{2}\right)_{6} \mathrm{O}_{4}(\mathrm{OH})_{6}\left(\mathrm{H}_{2} \mathrm{O}\right)_{8}\right]$ (at $\sim 1$ to 3 years), followed by soddyite $\left[\left(\mathrm{UO}_{2}\right)_{2} \mathrm{SiO}_{4} \cdot 2 \mathrm{H}_{2} \mathrm{O} ; \sim 3\right.$ years; $\left.\rho=4.63 \mathrm{~g} / \mathrm{cm}^{3} ; 668.17 \mathrm{~g} / \mathrm{mole}\right]$, uranophane $\left[\mathrm{CaUO}_{2} \mathrm{SiO}_{3}(\mathrm{OH})_{2} \cdot 5 \mathrm{H}_{2} \mathrm{O}\right.$; $\rho=3.90 \mathrm{~g} / \mathrm{cm}^{3} ; 510.3 \mathrm{~g} / \mathrm{mole}$ ], and other alkali and alkaline earth uranyl silicates (after 4 to 7 years). Accompanying decreases in $\mathrm{pH}$ and alkali, alkaline earth, and silicon solution concentrations also were observed as the mineralization progressed.

Similar, though likely much slower progression (because of lower temperatures and lower solute concentrations), would be expected for the $\mathrm{K}$ Basin sludge. Note that becquerelite [formed from schoepite and the calcite, $\mathrm{CaCO}_{3}\left(\rho=2.71 \mathrm{~g} / \mathrm{cm}^{3} ; 100.1 \mathrm{~g} /\right.$ mole $)$, sludge components] is present in the sludge by Reaction 6 . Sodium and potassium uranates also have been observed in some K Basin sludge samples (Delegard et al. 2000):

$$
24 \mathrm{UO}_{3} \cdot 2 \mathrm{H}_{2} \mathrm{O}+4 \mathrm{CaCO}_{3} \rightarrow 4 \mathrm{CaU}_{6} \mathrm{O}_{19} \cdot 11 \mathrm{H}_{2} \mathrm{O}+4 \mathrm{H}_{2} \mathrm{O}+4 \mathrm{CO}_{2} \uparrow
$$

\subsection{Assumed Chemistry and End State of Reacted Fuel Pieces}

The sludge stored in vented containers will contain some dissolved oxygen, and a mechanism exists to replenish the oxygen as it is consumed. Therefore, to some extent, the available oxygen will allow uranium oxides to further oxidize and hydrate in accordance with Reactions 4 and 5. Due to radiolysis of 
water, some oxygen may also be available to sludge stored in containers with a check valve/gas trap on the vent line. However, regardless of the storage container configuration, complete conversion of all uranium to $\mathrm{UO}_{2.86} \cdot 1.5 \mathrm{H}_{2} \mathrm{O}$ and $\mathrm{UO}_{3} \cdot 2 \mathrm{H}_{2} \mathrm{O}$ is not expected. The supply of oxygen to the sludge will be limited by diffusion, and radiolytic oxygen generation inside the sludge will be limited by the assumed 30-year storage period (see Appendix A). Other non-uranium species in the sludge may also consume/bind with oxygen. Finally, as demonstrated in gas generation testing ${ }^{(a)}$ the presence of an overlying sludge layer slows down the rate at which uranium metal (and presumably, uranium oxides) reacts.

Given these factors, for this analysis, it has been assumed that the end state (i.e., state after 30 years of containerized storage) for uranium metal corrosion is a 50/50 ( $\mathrm{U}$ basis) combination of the products of Reactions 2 and 4 (i.e., the most frequently observed identifiable uranium compounds during XRD analysis). The combined equation (two times Reaction $2+$ Reaction 5) is:

$$
2 \mathrm{U}_{(\text {metal })}+0.375 \mathrm{O}_{2}+6.5 \mathrm{H}_{2} \mathrm{O} \rightarrow \mathrm{UO}_{2.25}+\mathrm{UO}_{3} \cdot 2 \mathrm{H}_{2} \mathrm{O}+4.5 \mathrm{H}_{2}
$$

or

$$
\mathrm{U}_{\text {(metal) }}+0.188 \mathrm{O}_{2}+3.25 \mathrm{H}_{2} \mathrm{O} \rightarrow \mathrm{UO}_{2.63} \cdot \mathrm{H}_{2} \mathrm{O}+2.25 \mathrm{H}_{2}
$$

The "average" dry particle density of the uranium corrosion product mixture, $\mathrm{UO}_{2.25}+\mathrm{UO}_{3} \cdot 2 \mathrm{H}_{2} \mathrm{O}$ (or $\mathrm{UO}_{2.63} \cdot \mathrm{H}_{2} \mathrm{O}$ ) is calculated to be approximately $6.60 \mathrm{~g} / \mathrm{cm}^{3}$. (b)

In comparison with sample data in Table 2.5 , a dry particle density of $6.6 \mathrm{~g} / \mathrm{cm}^{3}$ for an end-state product for the complete conversion of pure uranium metal to oxide/hydrates appears to be reasonable but conservative. In Table 2.5, the sample with a high total uranium metal content that exhibits the lowest dry particle density is $\mathrm{KE}$ canister sample $96-06 \mathrm{M}(83 \mathrm{wt} \%$ uranium total, dry particle density $=6.90)$. [Note, KE consolidated canister sludge sample KC-2/3 (250 to $500 \mu \mathrm{m}$ size fraction) also exhibited a dry particle density of about 6.91 . However, the KC-2/3 P250 (250 to $6350 \mu \mathrm{m})$ only contained $35.2 \mathrm{wt} \%$ uranium (dry weight basis), and about $65 \mathrm{wt} \%$ of the KC-2/3 P250 sample was made up of particles between 250 and $500 \mu \mathrm{m}$.]

Test results (Poloski et al. 2002) suggest that the consolidated sludge samples, KC-2/3 M250 (canister sludge), KC-4 M250 (floor - between barrels) and KC-5 M250 (floor - away from barrels) did not change significantly in terms of settled density and percent solids (in settled sludge) after 2 years of sealed storage in the hot cell environment $\left(\sim 32^{\circ} \mathrm{C}\right)$. Therefore, it is probable, for some of the sludges in Table 2.5, that the reported dry particle densities are representative of sludge that has undergone nearfinal oxidation and hydration (i.e., volume expansion near completion).

(a) Silvers, K. L. August 3, 2001. "Preliminary Results from Gas Generation Series III Testing." Letter to W. W. Rutherford, Fluor Hanford. 43610-L01, Pacific Northwest National Laboratory, Richland, Washington.

(b) Assuming $0.5 \mathrm{~g} \mathrm{U}$ (metal) each to produce $\mathrm{UO}_{2.25}$ and $\mathrm{UO}_{3} \cdot 2 \mathrm{H}_{2} \mathrm{O}$,

$$
\text { density }=\frac{\text { Mass }\left[\mathrm{UO}_{2.25}+\mathrm{UO}_{3} \cdot 2 \mathrm{H}_{2} \mathrm{O}\right]}{\text { Volume }\left[\mathrm{UO}_{2.25}+\mathrm{UO}_{3} \cdot 2 \mathrm{H}_{2} \mathrm{O}\right]}=\frac{[0.576+0.676] \mathrm{g}}{[0.051+0.139] \mathrm{cm}^{3}}=6.60 \mathrm{~g} / \mathrm{cm}^{3}
$$




\subsection{Assumed Controlling Chemistry of Non-Metallic Uranium Under Partially Oxic Conditions}

The uranium (non-metallic) oxides/hydrates in canister sludge and floor sludge can potentially undergo further oxidation and hydration and increase in volume. The extent of expansion is dependent on the initial uranium compound distribution and the end-state compound distribution. To calculate expansion factors, it has been assumed that the end states of the non-metallic uranium are the same for all sludge types. However, based on the closed canister environment, the assumed starting-state non-metallic uranium compound distributions of KW canister sludge differ from those of the KE canister and floor sludge.

\subsubsection{Starting State of Non-Metallic Uranium in K Basin Sludge}

KE Canister, KE Floor, KW Floor, and KW NLOP Sludge: Based on XRD data and interpretations, many high-uranium-content canister sludges were judged here to contain primarily $\mathrm{UO}_{2}, \mathrm{U}_{4} \mathrm{O}_{9}\left(\mathrm{UO}_{2.25}\right)$, and $\mathrm{UO}_{3} \cdot 2 \mathrm{H}_{2} \mathrm{O}$ (Table 2.4). Therefore, for the KE floor, KE canister, KW floor and KW NLOP sludge, it has been assumed that the non-metallic uranium in these sludge types starts with an equal uranium mole fraction for each of these three compounds, yielding a nominal starting-state composition of $\mathrm{UO}_{2.42} \cdot 0.66 \mathrm{H}_{2} \mathrm{O}$ (molecular weight $=288.6$ ). The particle density of the starting oxide/hydrate mixture is calculated to be $7.53 \mathrm{~g} / \mathrm{cm}^{3}$. (a) The uranium content for $\mathrm{UO}_{2.42} \cdot 0.66 \mathrm{H}_{2} \mathrm{O}$ on a dry weight basis is $83.5 \%$, which is equal to or greater than that of the canister sludge samples listed in Table 2.5, with the exception of KE canister sludge sample 96-05 (88\% uranium).

KW Canister Sludge: The KW canisters are closed, and any gas generated is vented through a gas trap/release system. Also, an oxygen-scavenging corrosion inhibitor was added at the time spent fuel assemblies were loaded into the KW canisters. As a result, corrosion of the spent fuel in the KW canisters has largely occurred under anoxic conditions in accordance with Reactions 1, 2, and 3.

Therefore, it has been assumed that the non-metallic uranium in KW canister sludge starts with an equal uranium mole fraction of $\mathrm{UO}_{2}$ and $\mathrm{U}_{4} \mathrm{O}_{9}\left(\mathrm{UO}_{2.25}\right)$, yielding a nominal starting-state composition of $\mathrm{UO}_{2.13}$ (molecular weight $=272$ ). This composition is also near that postulated for the product of anoxic reduction of $\mathrm{U}$ metal with water (Hilton 2000) and observed in corrosion of crushed $\mathrm{N}$ reactor fuel during gas generation testing [see footnote (a) on p. 2.8]. The particle density of $\mathrm{UO}_{2.13}$ is calculated to be 11.1 $\mathrm{g} / \mathrm{cm}^{3}$, (b) which is significantly greater than the $7.53 \mathrm{~g} / \mathrm{cm}^{3}$ of $\mathrm{UO}_{2.42} \cdot 0.66 \mathrm{H}_{2} \mathrm{O}$. The data in Table 2.5 from whole KW canister samples and receiver samples (samples denoted with suffix "Rec") confirm that KW canister sludge exhibits a relatively high uranium content and density.

(a) Assuming $0.333 \mathrm{~g} \mathrm{U}_{\text {(metal) }}$ each to produce $\mathrm{UO}_{2.25}, \mathrm{UO}_{2}$, and $\mathrm{UO}_{3} \cdot 2 \mathrm{H}_{2} \mathrm{O}$.

$$
\text { density }=\frac{\text { Mass }\left[\mathrm{UO}_{2.25}+\mathrm{UO}_{2}+\mathrm{UO}_{3} \cdot 2 \mathrm{H}_{2} \mathrm{O}\right]}{\text { Volume }\left[\mathrm{UO}_{2.25}+\mathrm{UO}_{2}+\mathrm{UO}_{3} \cdot 2 \mathrm{H}_{2} \mathrm{O}\right]}=\frac{[0.384+0.378+0.451] \mathrm{g}}{[0.0340+0.0345+0.0926] \mathrm{cm}^{3}}=7.53 \mathrm{~g} / \mathrm{cm}^{3}
$$

(b) Assuming $0.5 \mathrm{~g} \mathrm{U}_{\text {(metal) }}$ each to produce $\mathrm{UO}_{2.25}$ and $\mathrm{UO}_{2}$,

$$
\text { density }=\frac{\text { Mass }\left[\mathrm{UO}_{2.25}+\mathrm{UO}_{2}\right]}{\text { Volume }\left[\mathrm{UO}_{2.25}+\mathrm{UO}_{2}\right]}=\frac{[0.576+0.567] \mathrm{g}}{[0.051+0.052] \mathrm{cm}^{3}}=11.1 \mathrm{~g} / \mathrm{cm}^{3}
$$




\subsubsection{End State of Non-Metallic Uranium}

For the sludge expansion calculations, it is assumed that the end state of the non-metallic uranium under oxic conditions is the same as the end state for fuel piece sludge (i.e., equal $\mathrm{U}$ masses of $\mathrm{UO}_{2.25}$ and $\mathrm{UO}_{3} \cdot 2 \mathrm{H}_{2} \mathrm{O}$ or $\mathrm{UO}_{2.63} \cdot \mathrm{H}_{2} \mathrm{O}$ ) with a particle density of $6.60 \mathrm{~g} / \mathrm{cm}^{3}$.

Under partially oxic conditions, the representative oxidation/hydration reaction of the starting-state nonmetallic uranium compounds to form the end-state $\mathrm{UO}_{2.63} \cdot \mathrm{H}_{2} \mathrm{O}$ for $\mathrm{KE}$ floor, $\mathrm{KE}$ canister, $\mathrm{KW}$ floor and KW NLOP sludge is given in Reaction 8:

$$
\mathrm{UO}_{2.42} \cdot 0.66 \mathrm{H}_{2} \mathrm{O}+0.105 \mathrm{O}_{2}+0.34 \mathrm{H}_{2} \mathrm{O} \rightarrow \mathrm{UO}_{2.63} \cdot \mathrm{H}_{2} \mathrm{O}
$$

The representative oxidation/hydration reaction of the starting-state non-metallic uranium compounds to form the end-state $\mathrm{UO}_{2.63} \cdot \mathrm{H}_{2} \mathrm{O}$ for $\mathrm{KW}$ canister sludge is given in Reaction 9, a rounded combination of Reactions 3 and $5\left(\mathrm{UO}_{2.125}+0.1875 \mathrm{O}_{2}+1.125 \mathrm{H}_{2} \mathrm{O} \rightarrow \mathrm{UO}_{2.625} \cdot \mathrm{H}_{2} \mathrm{O}+0.125 \mathrm{H}_{2}\right)$ :

$$
\mathrm{UO}_{2.13}+0.185 \mathrm{O}_{2}+1.13 \mathrm{H}_{2} \mathrm{O} \rightarrow \mathrm{UO}_{2.63} \cdot \mathrm{H}_{2} \mathrm{O}+0.13 \mathrm{H}_{2}
$$

\subsection{Summary of Corrosion-Based Volumetric Expansion Parameters}

The results of the corrosion-based expansion factor analyses are summarized in Table 2.6. The updated values should be used for safety and design basis calculations. These values do not account for the sludge expansion from gas retention (discussed in Section 3.0). Table 2.6 includes 1) the recommended and calculated volume expansion factors (end-state settled sludge volume divided by the starting settled sludge volume); 2) water consumption from chemical reactions; 3 ) required initial free water addition to provide for both sludge expansion and consumption of water; 4) the sludge fill level (percent of the container volume that can initially be filled with settled sludge); and 5) the overall volume (sludge + water) expansion or contraction (i.e., total volume change when sludge reacts to its end state).

The required initial free water shown in the table does not account for water that may be lost from the container by evaporation during storage. Estimates of the water loss rates from the LDCs by evaporation are provided in Fuller (2002). For all cases in Table 2.6, if containers are initially loaded with sufficient free water to keep the end-state sludge saturated, the final volume (expanded sludge) will be equal to or less than the initial volume (starting-state sludge + required free water).

As shown in Table 2.6 the volumetric expansion of fuel piece sludge under the partially oxic corrosion chemistry is substantial (final volume is 7.5 times that of the initial starting-state volume). However, for comparison, under extreme worst-case expansion conditions for fuel piece sludge [highly oxic storage; $100 \%$ complete conversion of $\mathrm{U}_{\text {(metal) }}$ to studtite $\left(\mathrm{UO}_{4} \cdot 4 \mathrm{H}_{2} \mathrm{O}\right)$ ], the end-state sludge volume would be 11.9 times that of the starting-state sludge (Schmidt and Delegard 2002). During the assumed maximum 30 -year storage period of K Basin sludge at T Plant, conversion of all uranium compounds to studtite is not expected, as discussed in Appendix A. 
Table 2.6. Summary of Expansion Factors, Water Consumption, and Initial Container Fill Levels for Containerized K Basin Sludge from Expansion Due to Uranium Corrosion (Expansion from Gas Retention Not Included)

\begin{tabular}{|c|c|c|c|c|c|c|c|c|c|c|}
\hline \multirow[t]{2}{*}{ Sludge Type } & \multicolumn{2}{|c|}{$\begin{array}{l}\text { Sludge Expansion } \\
\text { Factor }{ }^{(\mathrm{a})} \text { (volume } \\
\text { final/volume initial) }\end{array}$} & \multicolumn{2}{|c|}{$\begin{array}{l}\text { Water Consumption }{ }^{(b)} \\
\text { (g per L initial sludge) }\end{array}$} & \multicolumn{2}{|c|}{$\begin{array}{c}\text { Required Free } \\
\text { Water }^{(c)} \text { (L water per } \\
\text { L initial sludge) } \\
\end{array}$} & \multicolumn{2}{|c|}{$\begin{array}{l}\text { Sludge Fill Level }{ }^{(\mathrm{d})} \\
\text { (\% of initial volume } \\
\text { occupied by sludge) }\end{array}$} & \multicolumn{2}{|c|}{$\begin{array}{l}\text { Total Volume } \\
\text { Change }\left(\%{ }^{(\mathrm{e})}\right)\end{array}$} \\
\hline & Recom'd $^{(\mathbf{f})}$ & Calc. $^{(\mathrm{g})}$ & Recom'd $^{(f)}$ & Calc. ${ }^{(\mathrm{g})}$ & Recom'd $^{(f)}$ & Calc. $^{(\mathrm{g})}$ & Recom'd $^{(f)}$ & Calc. ${ }^{(\mathrm{g})}$ & Recom'd $^{(\mathbf{f})}$ & Calc. ${ }^{(\mathrm{g})}$ \\
\hline KE Canister Sludge & 1.33 & 1.22 & 96 & 64 & 0.34 & 0.23 & 75 & 81 & -0.75 & -0.81 \\
\hline KE Floor Sludge & 1.06 & 1.04 & 19 & 13 & 0.064 & 0.043 & 88 & 92 & -0.38 & -0.29 \\
\hline $\begin{array}{l}\text { 40/60 Volume } \% \\
\text { KE Canister:Floor } \\
\text { Sludge Mixture } \\
\end{array}$ & 1.17 & 1.11 & 50 & 33 & 0.18 & 0.12 & 85 & 89 & -0.85 & -0.89 \\
\hline $\begin{array}{l}\text { KW Floor, KW } \\
\text { NLOP (Same as KE } \\
\text { Floor) }\end{array}$ & 1.06 & 1.04 & 19 & 13 & 0.064 & 0.043 & 88 & 92 & -0.38 & -0.29 \\
\hline KW Canister Sludge & \multicolumn{2}{|c|}{2.4} & \multicolumn{2}{|c|}{267} & \multicolumn{2}{|c|}{1.42} & \multicolumn{2}{|l|}{41} & \multicolumn{2}{|c|}{-0.83} \\
\hline $\begin{array}{l}\text { Sludge Fuel Piece } \\
\text { Sludge }\end{array}$ & \multicolumn{2}{|c|}{7.5} & \multicolumn{2}{|c|}{2310} & \multicolumn{2}{|c|}{7.52} & \multicolumn{2}{|l|}{12} & \multicolumn{2}{|l|}{-12} \\
\hline $\begin{array}{l}55 / 45 \text { Volume \% Fuel } \\
\text { Piece:KW Canister } \\
\text { Sludge Mixture }\end{array}$ & \multicolumn{2}{|c|}{5.2} & \multicolumn{2}{|c|}{1390} & \multicolumn{2}{|c|}{4.78} & \multicolumn{2}{|l|}{17} & \multicolumn{2}{|l|}{-10} \\
\hline \multirow{2}{*}{\multicolumn{11}{|c|}{$\begin{array}{l}\text { (a) Final volume of end-state settled sludge after corrosion reactions (assuming sufficient initial free water to keep the sludge saturated) divided by the volume of } \\
\text { starting-state settled sludge. }\end{array}$}} \\
\hline & & & & & & & & & & \\
\hline \multirow{2}{*}{\multicolumn{11}{|c|}{ (d) Assuming a container is filled to $100 \%$ filled of its capacity with starting-state }} \\
\hline & & & & & & & & & & \\
\hline \multirow{2}{*}{\multicolumn{11}{|c|}{$\begin{array}{l}\text { These fill levels do not account for evaporation of water during storage or any volume for vapor space. } \\
\text { (e) Total volume change }=100 \times \text { [ }[1 \text { - (final total volume after full expansion)/(volume initial sludge + volume required free water)]. } \\
\text { (f) Recom'd = Recommended value; derived by multiplying percent expansion and water consumed by } 1.5 \text { to account for uncertainties in the uranium composition of } \\
\text { the starting-state and end-state sludge for KE floor, KE canister, KW floor, and KW NLOP sludge. An expansion factor multiplier is not recommended for KW } \\
\text { canister sludge or fuel piece sludge. }\end{array}$}} \\
\hline & & & & & & & & & & \\
\hline \multirow{2}{*}{\multicolumn{11}{|c|}{$\begin{array}{l}\text { (g) Calc. = Calculated value; directly calculated from updated input parame } \\
\text { (h) Design and safety basis composition of KE sludge loaded into LDCs. }\end{array}$}} \\
\hline & & & & & & & & & & \\
\hline \multicolumn{11}{|c|}{$\begin{array}{l}\text { (i) Preliminary estimate of approximate nominal composition of KOP sludge until validated as a design basis. Values in this row should not be considered safety or } \\
\text { design basis values for the KOP sludge. }\end{array}$} \\
\hline
\end{tabular}




\subsection{Expansion from Gas Retention}

Some of the hydrogen gas generated from the corrosion of uranium metal and conversion of $\mathrm{UO}_{2}$ to $\mathrm{UO}_{2.25}$ may be retained as bubbles within the sludge matrix. Those entrapped bubbles will expand the sludge bed volume and, therefore, will affect how much sludge can be loaded into a container. The entrapped gas bubbles will also impact the overall thermal conductivity and heat capacity of the sludge bed. Gauglitz and Terrones (2002) performed an analysis to estimate the maximum gas holdup (volume fraction gas) that could occur for KE sludge stored in LDCs, assuming uniform gas generation (i.e., uniform distribution of metallic uranium particles) within the sludge. Their analysis was based on existing literature data on bubble retention and $\mathrm{K}$ Basin sludge characterization data. Existing data show that the maximum gas fraction varies, depending on physical properties and the configuration of the sludge.

For the KE sludge gas retention analysis performed by Gauglitz and Terrones (2002), it was assumed that the maximum gas retention values measured during uniform gas generation testing with bentonite clay simulants having known (measured) shear strengths could be used to represent the expected gas retention values for $\mathrm{K}$ Basin sludges exhibiting the same respective shear strengths. In addition, it was assumed that the LDCs would be filled with discrete layers of sludge, with the shear strengths for each layer randomly assigned based on all available $\mathrm{K}$ Basin shear strength measurements. With these two assumptions, a probabilistic analysis was performed based on the results of 10,000 container-loading simulations. The results showed that an LDC with at least five randomly selected layers of K Basin sludge has a $99 \%$ probability of retaining less than $35 \%$ (vol) gas. Accordingly, under the assumption of uniform gas generation, the maximum gas retention for KE sludge stored in an LDC was estimated to be $35 \%$.

The $35 \%$ gas retention value for KE sludge loaded by layers into an LDC is not appropriate for the KW sludge streams, however. For the KW sludge disposition, the sludge may be stored in smaller containers, and loaded in such a manner that layers may not be formed. Of the 32 actual sludge shear strength measurements used by Gauglitz and Terrones (2002), only two measurements were taken using KW canister sludge samples (i.e., all other measurements involved KE sludge samples.) The two KW sludge shear strength values (from Samples 96-21 Rec and 96-24 Rec) correspond to a maximum $42 \%$ gas retention, a value higher than any of the KE sludge samples. Therefore, a $42 \%$ gas retention value is recommended for the sludge streams derived from KW canister sludge.

At the beginning of the containerized sludge storage period, fuel piece sludge will likely exist as relatively large independent particles and will retain gas bubbles primarily through capillary forces. In columns containing glass beads between 10 and $1000 \mu \mathrm{m}$, the highest values measured for bubble retention (by capillary forces) was about $20 \%$ (Gauglitz and Terrones 2002). However, as the fuel piece sludge corrodes, its composition and character will likely resemble KW canister sludge, with gas retention dominated by the shear strength of the sludge. Therefore, a $42 \%$ maximum gas retention value is also recommended for the fuel piece sludge.

At $42 \%$ gas retention, the volume occupied by the KW canister or fuel piece sludge will increase by a factor of $1.72[1 /(1-0.42)]$ relative to the sludge with no gas retention. 


\subsection{References}

Baker, R. B., T. L. Welsh, and B. J. Makenas. 2000. Sampling and Analysis Plan for Sludge from 105-K Basins to Support Transport to and Storage in T Plant. HNF-6479, Rev. 0, Fluor Hanford, Inc., Richland, WA.

Bredt, P. R., C. H. Delegard, A. J. Schmidt, and K. L. Silvers. 1999. Testing and Analysis of Consolidated Sludge Sample from 105K East Basin Floor and Canisters. PNNL-13341, Pacific Northwest National Laboratory, Richland, WA.

Delegard, C. H., S. A. Bryan, A. J. Schmidt, P. R. Bredt, C. M. King, R. L. Sell, L. L. Burger, and K. L. Silvers. 2000. Gas Generation from K East Basin Sludges - Series I Testing. PNNL-13320, Pacific Northwest National Laboratory, Richland, WA.

Elmore, M. R., A. J. Schmidt, K. L. Silvers, B. M. Thornton, and S. R. Gano. 2000. Chemical and Radiochemical Analysis of Consolidated Sludge Samples for the K East Basin. PNNL-13360, Pacific Northwest National Laboratory, Richland, WA.

Fuller, E. L. 2002. Accident and Thermal Analysis for Storing K East Basin Sludge at T Plant. HNF-12563, Rev. 0, Polestar Applied Technology, Inc., Richland, WA.

Gauglitz, P. A., and G. Terrones. 2002. Estimated Maximum Gas Retention from Uniformly Dispersed Bubbles in K Basin Sludge Stored in Large Diameter Containers. PNNL-13893, Pacific Northwest National Laboratory, Richland, WA.

Hilton, B. A. 2000. Review of Oxidation Rates of DOE Spent Nuclear Fuel Part 1: Metallic Fuel. ANL-00/24, Argonne National Laboratory, Idaho Falls, ID.

Makenas, B. J. 2000. Data Objectives for Analysis of Hanford K Basins Sludge to Support Transport to and Storage in T Plant. HNF-5345, Rev. 0, Fluor Hanford, Inc., Richland, WA.

Makenas, B. J., T. L. Welsh, R. B. Baker, D. R. Hansen, and G. R. Golcar. 1996. Analysis of Sludge from Hanford K East Basin Floor and Weasel Pit. WHC-SP-1182, Westinghouse Hanford Company, Richland, WA.

Makenas, B. J., T. L. Welsh, R. B. Baker, E. W. Hoppe, A. J. Schmidt, J. Abrefah, J. M. Tingey, P. R. Bredt, and G. R. Golcar. 1997. Analysis of Sludge from Hanford K East Basin Canisters. HNF-SP-1201, DE\&S Hanford, Inc., Richland, WA.

Makenas, B. J., T. L. Welsh, R. B. Baker, G. R. Golcar, P. R. Bredt, A. J. Schmidt, and J. M. Tingey. 1998. Analysis of Sludge from Hanford K West Basin Canisters. HNF-1728, Rev. 0, Fluor Daniel Hanford, Richland, WA.

Makenas, B. J., T. L. Welsh, P. R. Bredt, G. R. Golcar, A. J. Schmidt, K. L. Silvers, J. M. Tingey, A. H. Zacher, and R. B. Baker. 1999. Analysis of Internal Sludge and Cladding Coatings from $N$-Reactor Fuel Stored in Hanford K Basins. HNF-3589, Rev. 0, Fluor Daniel Hanford, Richland, WA. 
Pearce, K. L. 2001. 105-K Basin Material Design Basis Feed Description for Spent Nuclear Fuel Project Facilities, Volume 2, Sludge. HNF-SD-SNF-TI-009, Rev. 4, Vol. 2, Fluor Hanford, Richland, WA.

Pearce, K. L. 2002. Spent Nuclear Fuel Project Technical Databook, Volume 2, Sludge. HNF-SD-SNF-TI-015, Rev. 9, Vol. 2, Fluor Hanford, Richland, WA.

Plys, M. G., and K. L. Pearce. 2001. Supporting Basis for Spent Nuclear Fuel Project Sludge Technical Databook. SNF-7765, Rev. 0, EDT 629145, Fluor Hanford, Richland, WA.

Plys, M. G., and K. L. Pearce. 2002. Supporting Basis for Spent Nuclear Fuel Project Sludge Technical Databook. SNF-7765, Rev. 1, Fluor Hanford, Richland, WA.

Poloski, A.P., P. R. Bredt, A. J. Schmidt, R. G. Swoboda, A. W. Chenault, and S. R. Gano. 2002.

Thermal Conductivity and Shear Strength of K Basin Sludge. PNNL-13911, Pacific Northwest National Laboratory, Richland, WA.

Schmidt, A. J., and C. H. Delegard. 2002. Assessment of K Basin Sludge Volume Expansion Resulting from Uranium Corrosion During Storage. PNNL-13786, Pacific Northwest National Laboratory, Richland, WA.

Wronkiewicz, D. J., J. K. Bates, S. F. Wolf, and E. C. Buck. 1996. "Ten-Year Results from Unsaturated Drip Tests with $\mathrm{UO}_{2}$ at $90^{\circ} \mathrm{C}$ : Implications for the Corrosion of Spent Nuclear Fuel." Journal of Nuclear Material 238:78-95. 


\title{
Appendix A
}

\section{Supporting Analysis for Uranium Compound Distribution After 30-Year Storage in LDC}

\author{
Prepared by G. A. Whyatt
}

[originally included as Appendix C in Plys and Pearce (2002)] 


\title{
Appendix A \\ Supporting Analysis for Uranium Compound Distribution After 30-Year Storage in LDC
}

\author{
Prepared by G. A. Whyatt
}

The following text originally appeared in Appendix C of Plys and Pearce (2002). While it was written to specifically address KE sludge storage in Large Diameter Containers (LDCs), the mechanisms described (diffusion and radiolysis) and the general conclusions regarding the end-state uranium compound distributions also apply to the KW sludge streams.

\section{Introduction}

K Basin sludge contains metallic uranium and uranium oxides that will corrode and hydrate while being stored within LDCs. As these reactions proceed, the sludge is expected to increase in volume due to the reduction in density associated with the reactions. The purpose of this attachment is to explain and document the assumptions used to estimate the 30-year oxidation state of uranium compounds for sludge stored in LDCs. This end state is important in determining the maximum sludge expansion that might be expected due to corrosion reactions.

\section{Background}

For purposes of the analysis, all non-uranium species, including iron and aluminum corrosion products, zirconium cladding, ion exchange material, wind-blown debris, and sand, were assumed to be inert. This is equivalent to assuming that expansive corrosion reactions are dominated by the corrosion of uranium compounds. Thus, while there may be small amounts of incompletely oxidized iron or other materials that will react during storage, they are neglected in the analysis. The degree of volumetric expansion that will be experienced during storage depends upon the selection of the initial and final corrosion products for uranium. Schmidt and Delegard (2002) examined the uranium compound corrosion reactions in the presence and absence of oxygen. In the absence of oxygen, the uranium will corrode in water to $\mathrm{UO}_{2.25}$ (particle density $11.3 \mathrm{~g} / \mathrm{cm}^{3}$ ). In the presence of oxygen, corrosion may continue to form schoepite $\mathrm{UO}_{3} \cdot \mathrm{xH}_{2} \mathrm{O}$ (particle density $4.87 \mathrm{~g} / \mathrm{cm}^{3}$ ). The LDC will have a filtered vent so that the air space above the sludge/liquid will have a mechanism to replenish oxygen consumed. In Schmidt and Delegard (2002), several factors concerning storage conditions are noted which will tend to interfere with complete oxidation of the sludge to schoepite. These factors included:

- the outflow of hydrogen which will interfere with oxygen inflow

- consumption of oxygen by non-uranium species

- the presence of a sludge layer which due to mass transfer resistance slows corrosion reactions

Based on this, an endstate corrosion product mix was selected consisting of a 50:50 mix of $\mathrm{UO}_{2.25}$ and metaschoepite $\left(\mathrm{UO}_{3} \cdot 2 \mathrm{H}_{2} \mathrm{O}\right.$, particle density $\left.4.87 \mathrm{~g} / \mathrm{cm}^{3}\right)$. Several review comments generated during the technical review of report SNF-7765 Rev. 1 (Plys and Pearce 2002) required a revision in the logic supporting the end state corrosion mixture. The comments noted the following points: 
- Hydrogen outflow from corrosion only continues while corrosion is active. After corrosion to $\mathrm{UO}_{2.25}$ is complete the hydrogen source would stop and air ingress would be possible.

- Consumption of oxygen by non-uranium species is negligible due to the small quantity of these materials in the sludge.

- The presence of a sludge layer will slow, but not stop, oxygen diffusion. Hence, it is not appropriate to describe the "end state" corrosion without specifying the time period. Ultimately, the true end state is for the uranium to be corroded to $\mathrm{UO}_{3} \cdot \mathrm{xH}_{2} \mathrm{O}$. (Further mineralization may also occur although the density changes are relatively small so they are not as important for sludge expansion.)

- The potential for oxygen to be generated by radiolysis needs to be considered in the analysis.

This attachment provides the updated rationale supporting the 50:50 mix of $\mathrm{UO}_{2.25}$ and $\mathrm{UO}_{3} \cdot 2 \mathrm{H}_{2} \mathrm{O}$ as the state of the sludge after 30 years of corrosion.

\section{Initial Uranium and Sludge State}

The initial oxide composition is unchanged from Schmidt and Delegard (2002), in which, based on XRD data and interpretations, the sludge uranium content is taken to be present initially as an equimolar mixture of $\mathrm{UO}_{2.25}, \mathrm{UO}_{2}$ and $\mathrm{UO}_{3} \cdot 2 \mathrm{H}_{2} \mathrm{O}$. This averages to a uranium compound formula of $\mathrm{UO}_{2.42} \cdot 0.66 \mathrm{H}_{2} \mathrm{O}$ with a particle density of $7.53 \mathrm{~g} / \mathrm{cm}^{3}$.

\section{Evaluation of Mass Transfer Limitations in Sludge}

A scoping analysis was performed to evaluate the potential for oxygen to be transported from the vapor space of the container down into the sludge layer to provide the oxygen needed to oxidize the uranium in the sludge.

There was assumed to be a $127 \mathrm{~cm}(50$-inch) deep sludge layer in an LDC. The air exchange to the plenum space of the vessel was assumed to be rapid enough to maintain atmospheric oxygen content within the plenum space. The water layer on top of the sludge was assumed to be in equilibrium with the air. Mass transfer of the oxygen into the sludge was assumed to be limited by the rate at which the oxygen could diffuse through the sludge. The sludge was assumed to prevent advection of liquid, ${ }^{\text {(a) }}$ but otherwise no credit was taken for the ability of a sludge to reduce the diffusion coefficient. The sludge was assumed to start with all uranium existing as $\mathrm{UO}_{2.25}$ at time $=0$. The reaction of $\mathrm{UO}_{2.25}$ with oxygen to form $\mathrm{UO}_{3} \cdot 2 \mathrm{H}_{2} \mathrm{O}$ was assumed to be rapid compared to diffusion.

The problem was solved in one dimension in an EXCEL spreadsheet using the iterative calculation capability to simulate a finite difference formulation of the problem. The diffusion calculation was performed with a time step of 1 hour and by dividing the $127 \mathrm{~cm}$ depth into 200 nodes resulting in a spatial resolution of $0.635 \mathrm{~cm}$. Within each node, both the oxygen concentration and $\mathrm{UO}_{2.25}$ concentration were tracked. Oxygen entering a node was consumed to oxidize the $\mathrm{UO}_{2.25}$ until all uranium was oxidized before it was used to increase the oxygen content of the cell. Once the uranium was depleted the oxygen diffused through the cell normally. To check the accuracy of the model, the

(a) As a result of this assumption the conclusions from this analysis could be invalidated if there is circulation of liquid within the sludge layer. Density differences due to thermal gradients or due to generated gases escaping to the surface are possible driving forces for circulation. 
uranium content was set to zero and the model results were compared to an analytical solution of the diffusion problem. For purposes of this scoping analysis, the model agreed satisfactorily with the analytical solution. A comparison is shown in Figure A.1.

The parameter input values used and the supporting rationales are as follows:

- Diffusivity: The sludge was assumed to have a diffusivity of $2 \times 10^{-5} \mathrm{~cm}^{2} / \mathrm{s}$, which is typical of aqueous solutes rather than specific to oxygen. The volume fraction water was treated as $=1$.

- Oxygen concentration at boundary: Based on $3 \mathrm{~cm}^{3} \mathrm{O}_{2} / 100 \mathrm{~g}$ water solubility at $20^{\circ} \mathrm{C}$ with Henry's Law assumption used to calculate the value in equilibrium with atmospheric air.

- Uranium Content: Two cases considered, $0.30 \mathrm{~g} \mathrm{U} / \mathrm{cm}^{3}$ and $0.04 \mathrm{~g} \mathrm{U} / \mathrm{cm}^{3}$ corresponding to the updated safety and design basis values for KE floor sludge.

\section{Results}

Figure A. 2 shows the penetration of the oxygen into the sludge for the case where there is $0.30 \mathrm{~g} \mathrm{U} / \mathrm{cm}^{3}$ within the sludge. The rate of penetration into the sludge is controlled by the uranium oxygen sink so that the concentration profiles are very nearly linear to the point where uranium is being oxidized. Over the assumed 30-year storage lifetime, the profile of oxidation to $\mathrm{UO}_{3}$ penetrates only $4 \%$ of the way into the sludge. Averaged over the depth of the sludge, the average oxidation goes from the initial state of $\mathrm{UO}_{2.42}$ to $\mathrm{UO}_{2.44}$ or about $10 \%$ of the way to the final assumed state of $\mathrm{UO}_{2.62}$.

A similar figure is shown in Figure A.3, where the uranium content is taken to be $0.04 \mathrm{~g} / \mathrm{cm}^{3}$. In this case the penetration of the oxidation front is much greater. At 30 years about $11.4 \%$ of the total uranium has been oxidized to the $\mathrm{UO}_{3}$ state. Averaged over the $\mathrm{LDC}$, the oxidation state increases from $\mathrm{UO}_{2.42}$ to $\mathrm{UO}_{2.486}$ or about $1 / 3$ of the way toward the assumed 30 -year composition which is $\mathrm{UO}_{2.62}$.

Note that while the depth of penetration increases for lower uranium contents, the extent of sludge expansion overall will be reduced due to the reduced quantity of corroding uranium. As the uranium content of the sludge increases the depth of penetration decreases. This will tend to limit the degree of sludge expansion due to uranium corrosion from oxygen diffusion into the sludge layer to a less than proportional relationship to uranium content. In either case, however, the oxygen diffusion appears sufficient only to provide a fraction of the oxidation that is assumed to occur over the 30 -year storage period.

Based on this analysis, it does not appear that diffusion of oxygen into the sludge within an LDC will be a significant source of uranium oxidation, especially if the sludge uranium content is high.

\section{Evaluation of Radiolysis Source for Oxidation}

A scoping analysis was performed to evaluate whether the uranium in sludge stored within an LDC might be oxidized by oxygen generated via radiolysis within the sludge layer. A simple calculation was performed as follows. From Delegard et al. (2000) Appendix C, two "G" values for hydrogen from radiolysis were obtained. These values are:

$$
\text { Expected typical value: } 0.13 \mathrm{~cm}^{3} \mathrm{H}_{2} /(\mathrm{hr}-\mathrm{kg} \mathrm{U})
$$


An apparent bounding value: $2 \mathrm{~cm}^{3} \mathrm{H}_{2} /(\mathrm{hr} \mathrm{kg} \mathrm{U})$

Assuming these are the result of radiolysis of water, the previous safety basis value for KE floor sludge of $0.15 \mathrm{~g} \mathrm{U} / \mathrm{cm}^{3}$ translates to: ${ }^{\text {(a) }}$

\section{Expected $1.21 \mathrm{e}-13 \mathrm{~mol} \mathrm{O}_{2} / \mathrm{s} / \mathrm{cm}^{3}$ settled \\ Bounding: $1.86 \mathrm{e}-12 \mathrm{~mol} \mathrm{O} / \mathrm{s} / \mathrm{cm}^{3}$ settled}

Assuming all generated oxygen is consumed in uranium corrosion reactions, the expected case results in about 62 years being required to generate the oxygen needed to oxidize the $\mathrm{UO}_{2.25}$ to $\mathrm{UO}_{3} \cdot 2 \mathrm{H}_{2} \mathrm{O}$. When applied to the starting oxidation state of $\mathrm{UO}_{2.42}$ the oxidation state after 30 years is estimated to be $\mathrm{UO}_{2.78}$ which is reasonably in agreement with the assumed value of $\mathrm{UO}_{2.62}$.

If the bounding $\mathrm{G}$ value is used a higher level of oxidation results. However, it is not clear whether the $\mathrm{G}$ value for $\mathrm{H}_{2}$ generation from Delegard et al. (2000) Appendix $\mathrm{C}$ is applicable to oxygen. While high $\mathrm{G}$ values for hydrogen are possible with organic material such as ion exchange resin these materials would not produce a proportional amount of oxygen as assumed here. In these cases, oxygen would not be generated in proportional quantities. The fact that the sludge in the basin currently is not highly oxidized would tend to discount the bounding $G$ value, which would oxidize all uranium in about 4 years. Some additional review of literature to select a more appropriate bounding $\mathrm{G}$ value for $\mathrm{O}_{2}$ would strengthen this analysis.

The current calculations do not account for decay of radionuclides. To the extent that shorter-lived radionuclides such as ${ }^{137} \mathrm{Cs}$ and ${ }^{90} \mathrm{Sr}$ are contributing (both $\sim 30$-year half life), the oxidation rate from radiolysis will decrease over time. Also, the current analysis assumes that all radiation is absorbed in the sludge so that radiation absorbed in the walls of the LDC or escaping the container is not accounted for.

The estimated radiation source imported from Delegard et al. (2000) Appendix C is arrived at by ratioing to the uranium content. If there is a better assumption to be used, that portion of the analysis should be modified. This is especially true if the radionuclide content could be much higher than indicated by ratioing to uranium content due to the presence of ion exchange resins concentrating the radionuclides.

In summary, the radiolysis source of oxygen is expected to provide sufficient oxygen to oxidize the uranium in the sludge to an oxidation state approximately consistent with the assumed 50:50 mix of $\mathrm{UO}_{2.25}$ and $\mathrm{UO}_{3} \cdot 2 \mathrm{H}_{2} \mathrm{O}$. While bounding $\mathrm{G}$ values indicate greater levels of oxidation, there are questions about the applicability of the $\mathrm{G}$ values to oxygen production. The current analysis could be refined in several aspects, some of which would tend to decrease the degree of oxidation expected.

(a) Note that while the safety basis value has been increased to $0.3 \mathrm{~g} / \mathrm{cm} 3$ the analysis uses a radiation source that is ratioed to the uranium content present. Thus, the rate of oxygen generation and the amount of uranium to be oxidized both vary linearly with the assumed uranium in the sludge. The time period to oxidize the available uranium is thus not dependent on the quantity of uranium in the sludge in this analysis. 


\section{Application of Safety Factor to Acknowledge Uncertainty in Analysis}

For the KE sludge, to account for the level of uncertainty in estimating the initial and final uranium compounds distributions, the estimated degree of sludge expansion and water consumption are multiplied by a factor of 1.5 .

With the application of the factor of $1.5 \mathrm{X}$ applied to water consumption and sludge expansion to account for uncertainty included, the selection of the final end state as a 50:50 mix of $\mathrm{UO}_{2.25}$ and $\mathrm{UO}_{3} \cdot 2 \mathrm{H}_{2} \mathrm{O}$ as the state of the sludge uranium compounds after 30 years of storage appears reasonable. As noted in the text of Plys and Pearce (2002), an expansion multiplier was judged to be unwarranted for the KW canister sludge and the fuel piece sludge.

\section{References}

Delegard, C. H., S. A. Bryan, A. J. Schmidt, P. R. Bredt, C. M. King, R. L. Sell, L. L. Burger, and K. L. Silvers. 2000. Gas Generation from K East Basin Sludges - Series I Testing. PNNL-13320, Pacific Northwest National Laboratory, Richland, WA.

Plys, M. G., and K. L. Pearce. 2002. Supporting Basis for Spent Nuclear Fuel Project Sludge Technical Databook. SNF-7765, Rev. 1, Fluor Hanford, Richland, WA.

Schmidt, A. J., and C. H. Delegard. 2002. Assessment of K Basin Sludge Volume Expansion Resulting from Uranium Corrosion During Storage. PNNL-13786, Pacific Northwest National Laboratory, Richland, WA. 


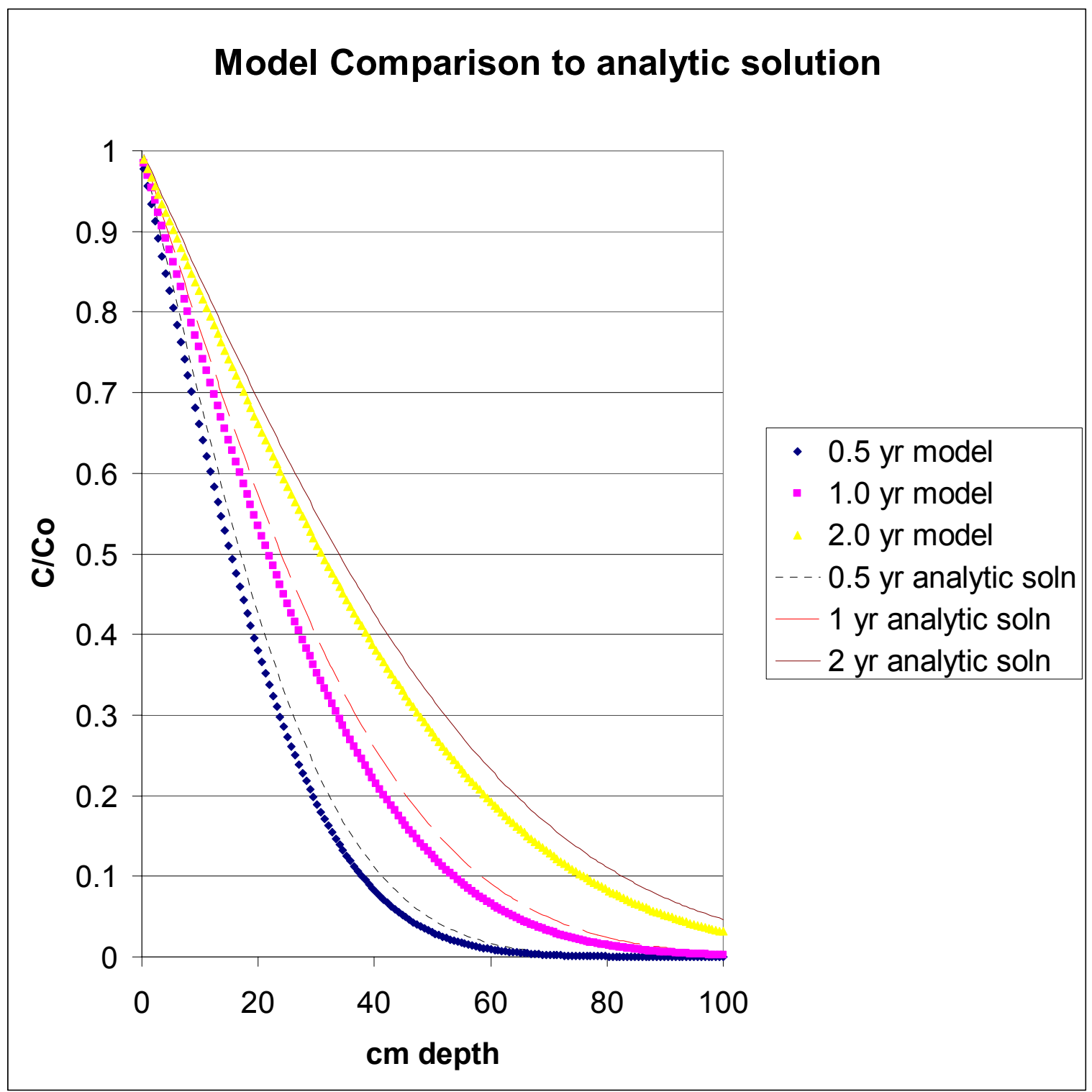

Figure A.1. Comparison of the analytical solution of the diffusion problem to results predicted by the numerical model at $0.5,1$, and 2 years. In order to obtain an analytical solution, the uranium oxygen sink has been set to zero in this case. The results confirm that the calculation model with the given time and spatial resolution provides reasonable results. The problem was calculated with a no-flux boundary at $127 \mathrm{~cm}$ in the numerical model and using a semi-infinite boundary condition in the analytical solution. 


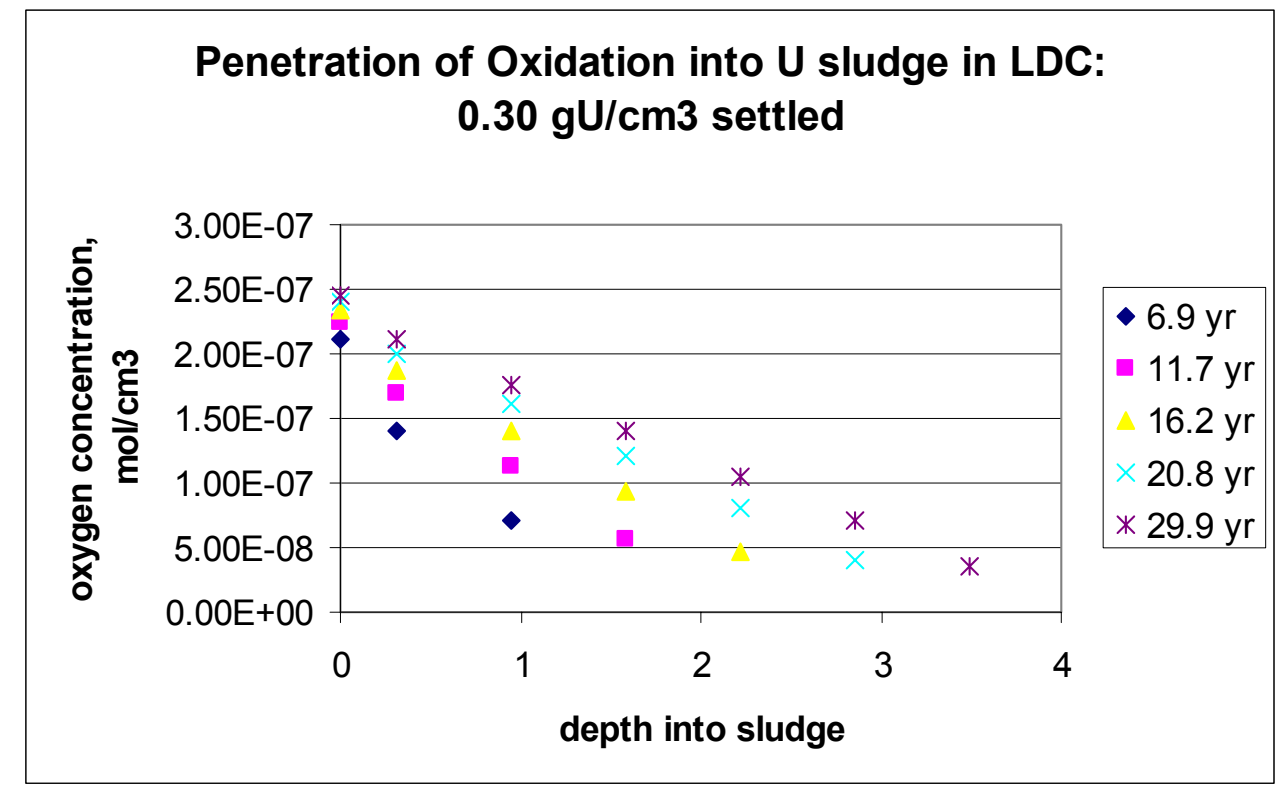

Figure A.2. Oxygen Profiles for Diffusion into Sludge Containing $0.30 \mathrm{gU} / \mathrm{cm}^{3}$. The oxygen profile penetrates only about $5 \mathrm{~cm}$ into the sludge over the first 30 years.

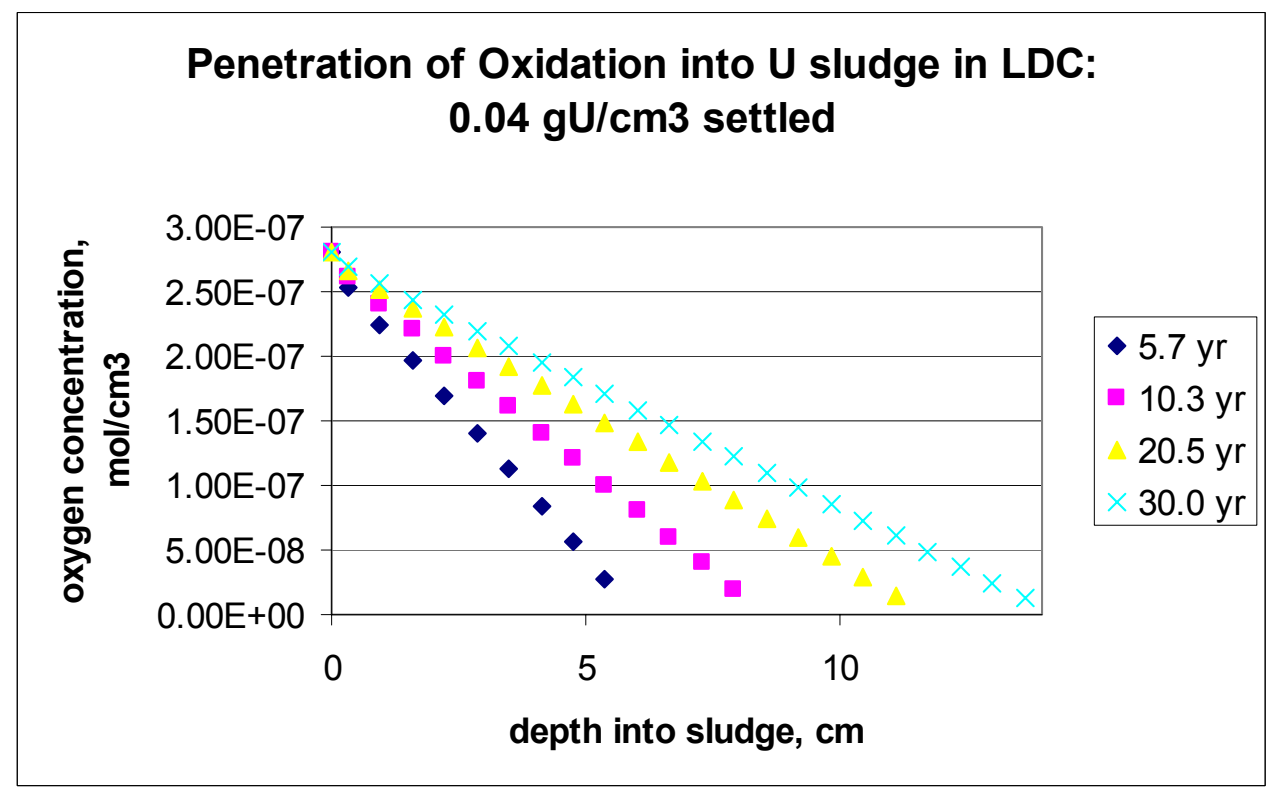

Figure A.3. Oxygen Profiles for Diffusion into Sludge Containing $0.04 \mathrm{gU} / \mathrm{cm}^{3}$. The oxygen profile penetrates only about $12 \mathrm{~cm}$ into the sludge over the first 30 years. 


\section{Appendix B}

\section{Volumetric Expansion of KW Canister Sludge}




\section{Appendix B}

\section{Volumetric Expansion of KW Canister Sludge}

This section describes the methodology used to calculate the parameters for the volumetric expansion of sludge due to corrosion reactions. KW canister sludge is evaluated here, since the volumetric expansion of KW canister sludge under partially oxic storage conditions was not examined in the earlier study (Schmidt and Delegard 2002).

\section{B.1 Starting State of KW Canister Sludge}

The KW canister sludge (as reported in Plys and Pearce 2002) nominally contains $1.5 \mathrm{~g} \mathrm{U} / \mathrm{cm}^{3}$, has a settled sludge density of $2.7 \mathrm{~g} / \mathrm{cm}^{3}$, and has a void fraction of 0.70 .

The proposed ${ }^{(\mathrm{a})}$ safety basis values for KW canister sludge are:

- $\operatorname{void}$ fraction $=0.65$ (proposed $^{(\text {a) }}$

- settled sludge density $=4.0 \mathrm{~g} / \mathrm{cm}^{3}$ (proposed $^{(\text {a) }}$

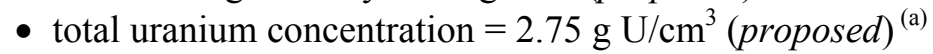

- $\mathrm{U}$ metal concentration $=5 \mathrm{wt} \%$ (settled sludge) $=0.05 \times 4.0 \mathrm{~g} / \mathrm{cm}^{3}=0.200 \mathrm{~g} \mathrm{U} / \mathrm{cm}^{3}$ (Plys and Pearce 2002).

Using the parameters for starting-state $\mathrm{KW}$ canister sludge, $1 \mathrm{~cm}^{3}$ of settled sludge contains:

$$
\begin{aligned}
& 0.65 \times 1 \mathrm{~g} / \mathrm{cm}^{3} \text { (water) }+0.2 \mathrm{~g}(\mathrm{U} \text { metal })+(2.75-0.200) \times(272 / 238) \mathrm{g} / \mathrm{cm}^{3} \\
& \left(\mathrm{UO}_{2.13}\right)+0.24 \mathrm{~g}(\text { non-U solids by diff. })=4.0 \mathrm{~g} .
\end{aligned}
$$

From these initial starting-state conditions, the KW canister sludge is $84 \mathrm{wt} \%$ solids $[(4.0-0.65) / 4.0]$ and has a total uranium concentration of $82 \mathrm{wt} \%$ (dry basis). The settled sludge density $\left(4.0 \mathrm{~g} / \mathrm{cm}^{3}\right)$ and the dry basis uranium concentration compare reasonably well to densities of KW canister sludge samples 96-16 and 96-17, as shown in Table 2.5.

\section{For the crosscheck on validity of starting-state conditions for KW canister sludge:}

To determine the density of the non-uranium-containing solids, mass and volume balances were performed while varying the sludge void fraction. Reasonable balances were obtained using a void fraction of 0.65 and a non-uranium-containing solids density of $3.1 \mathrm{~g} / \mathrm{cm}^{3}$. A void fraction of 0.65 is in good agreement with the KW canister sludge characterization data. Furthermore, a non-uraniumcontaining solids particle density of $3.1 \mathrm{~g} / \mathrm{cm}^{3}$ is the average particle density of gibbsite, goethite, and quartz, all of which were identified in the KW canister sludge. KW canister sludge also contains graphite particles $\left(1.12 \mathrm{~g} / \mathrm{cm}^{3}\right)$ and Zircaloy-2 cladding particles $\left.\left(6.5 \mathrm{~g} / \mathrm{cm}^{3}\right)\right]$.

(a) Safety basis chemical and physical property values for KW canister sludge have not been finalized [i.e., Pearce (2002) and Plys and Pearce (2002) list these values as "to be determined."] The proposed values are based on Plys and Pearce (2001), interpretation of KW canister characterization data, and mass and volume balances performed around KW canister sludge. 
From Section 2.6.1, the non-metallic uranium component is $\mathrm{UO}_{2.13}$, with a particle density of $11.1 \mathrm{~g} / \mathrm{cm}^{3}$.

From the particle density data and the void fraction assumptions, a calculation was performed to compare the volume of $4.0 \mathrm{~g}$ starting-state sludge (expected to be $1 \mathrm{~cm}^{3}$ ) using the starting-state composition given above.

Basis: $4.0 \mathrm{~g}$

$$
\begin{aligned}
\text { Volume }= & 0.65 \mathrm{~g} \text { water } /\left(1 \mathrm{~g} / \mathrm{cm}^{3}\right)+0.200 \mathrm{~g} \mathrm{U} \mathrm{U}_{\text {(metal) }} /\left(19 \mathrm{~g} / \mathrm{cm}^{3}\right)+(2.75-0.200 \mathrm{~g} \text { non-metal } \mathrm{U}) \\
& (272 / 238) /\left(11.1 \mathrm{~g} / \mathrm{cm}^{3}\right)+ \\
& 0.24 \mathrm{~g} \text { non-U solids } /\left(3.1 \mathrm{~g} / \mathrm{cm}^{3}\right) \\
= & \left.0.65 \mathrm{~cm}^{3} \text { (water) }+0.011 \mathrm{~cm}^{3} \mathrm{U}_{(\text {metal })}+0.264 \mathrm{~cm}^{3} \text { (non-metal } \mathrm{U}\right)+ \\
& 0.077 \mathrm{~cm}^{3} \text { (non-U solids) } \\
= & 1.00 \mathrm{~cm}^{3} \text {; i.e., the assumed starting-state conditions appear to be self-consistent. }
\end{aligned}
$$

\section{B.2 Sludge Level Expansion Factor}

The expansion factor can be determined by starting with a unit mass and volume $\left(1 \mathrm{~cm}^{3}\right)$ of starting-state canister sludge (Section 3.1). Next, the particle volumes of the various components (at their end states) are determined and summed, and the total settled sludge volume is calculated from the void fraction (assumed to be 0.75 ) of the fully oxidized/hydrated sludge.

The end-state particle volume of $\mathrm{UO}_{2.63} \cdot \mathrm{H}_{2} \mathrm{O}$ [from the uranium metal and $\mathrm{UO}_{2.13}$ ], plus non-uranium solids $(0.24 \mathrm{~g})$, starting with $1 \mathrm{~cm}^{3}$ of starting-state canister sludge is:

End-state volume of expanded particles

$$
\begin{aligned}
& =2.75 \mathrm{~g} \mathrm{U} x(298 / 238) /\left(6.6 \mathrm{~g} / \mathrm{cm}^{3}\right)+0.24 \mathrm{~g} \text { (non-uranium solids) } /\left(3.1 \mathrm{~g} / \mathrm{cm}^{3}\right) \\
& =0.522 \mathrm{~cm}^{3}\left(\mathrm{UO}_{2.63} \cdot \mathrm{H}_{2} \mathrm{O}\right)+0.077 \mathrm{~cm}^{3} \text { (non-uranium solids) } \\
& =0.60 \mathrm{~cm}^{3} \text { solids. }
\end{aligned}
$$

End-state settled sludge volume $=0.60 \mathrm{~cm}^{3}$ solids $\mathrm{x}\left(1 \mathrm{~cm}^{3}\right.$ sludge $/ 0.25 \mathrm{~cm}^{3}$ solids $)=2.40 \mathrm{~cm}^{3}$.

Expansion factor $=($ end-state volume $) /($ starting-state volume $)=2.40 \mathrm{~cm}^{3} / 1 \mathrm{~cm}^{3}=2.40 \sim 2.4$.

Therefore, the KW canister settled sludge volume is expected to increase to about 2.4 times its initial volume during containerized storage. 


\section{B.3 Total Volume Expansion for KW Canister Sludge}

Total volume expansion is defined here as the difference between the end-state expanded settled sludge volume and the sum of the starting-state settled sludge volume plus the required free water volume. For calculating the total volume expansion, it is assumed that enough water will be added to the initial canister sludge (starting state) to result in a final expanded settled sludge that stays just saturated (i.e., no free supernatant at completion of oxidation and hydration).

Starting basis: $1 \mathrm{~L}\left(1000 \mathrm{~cm}^{3}\right)$ canister sludge + initial free water.

Uranium metal

$$
=1000 \mathrm{~cm}^{3} \times 0.200 \mathrm{~g} \mathrm{U} / \mathrm{cm}^{3}=200 \mathrm{~g} \mathrm{U}(0.84 \text { mole } \mathrm{U}) \text { metal } / \mathrm{L} \text { canister sludge. }
$$

Water consumed in reactions with U metal (Reaction 7):

$$
\mathrm{U}_{\text {(metal) }}+0.188 \mathrm{O}_{2}+3.25 \mathrm{H}_{2} \mathrm{O} \rightarrow \mathrm{UO}_{2.63} \cdot \mathrm{H}_{2} \mathrm{O}+2.25 \mathrm{H}_{2}
$$

$=3.25$ moles $\mathrm{H}_{2} \mathrm{O} /$ mole $\mathrm{U}$ x 0.84 moles $\mathrm{U}$ x $18 \mathrm{~g} \mathrm{H}_{2} \mathrm{O} /$ mole $_{2} \mathrm{O}=49.1 \mathrm{~g} \mathrm{H}_{2} \mathrm{O}$.

Non-metallic uranium

$$
=1000 \mathrm{~cm}^{3} \times(2.75-0.200) \mathrm{g} \mathrm{U} / \mathrm{cm}^{3}=2550 \mathrm{~g}(10.7 \mathrm{~mole}) \mathrm{U} / \mathrm{L} \text { canister sludge. }
$$

Water consumed in conversion of non-metallic U in KW canister sludge (Reaction 9):

$$
\mathrm{UO}_{2.13}+0.185 \mathrm{O}_{2}+1.13 \mathrm{H}_{2} \mathrm{O} \rightarrow \mathrm{UO}_{2.63} \cdot \mathrm{H}_{2} \mathrm{O}+0.13 \mathrm{H}_{2}
$$

$=1.13$ mole $\mathrm{H}_{2} \mathrm{O} /$ mole $\mathrm{U}$ x 10.7 mole $\mathrm{U}$ x $18 \mathrm{~g} \mathrm{H}_{2} \mathrm{O} /$ mole $\mathrm{H}_{2} \mathrm{O}=218$ g $_{2} \mathrm{O}$.

Starting-state interstitial water $=0.65 \times 1000 \mathrm{~cm}^{3}=650 \mathrm{~cm}^{3}=650 \mathrm{~g}$.

After oxidation/hydration of $1 \mathrm{~L}$ starting-state canister sludge, the expanded end-state volume, $2.4 \mathrm{~L}=$ particle volume of uranium oxide hydrate + particle volume of non-uranium solids + end-state volume of water.

$$
\text { Volume of } \begin{aligned}
\mathrm{UO}_{2.63} \cdot \mathrm{H}_{2} \mathrm{O} & =\left[2.75 \mathrm{~g} \mathrm{U} / \mathrm{cm}^{3} \times 1000 \mathrm{~cm}^{3} \times(298 / 238)\right] /\left(6.6 \mathrm{~g} / \mathrm{cm}^{3}\right) \\
& =522 \mathrm{~cm}^{3} .
\end{aligned}
$$

Volume of non-uranium solids $=0.24 \mathrm{~g} / \mathrm{cm}^{3} \times 1000 \mathrm{~cm}^{3} /\left(3.1 \mathrm{~g} / \mathrm{cm}^{3}\right)=77 \mathrm{~cm}^{3}$.

$$
\text { End-state water }=2400 \mathrm{~cm}^{3}-522 \mathrm{~cm}^{3}-77 \mathrm{~cm}^{3}=1801 \mathrm{~cm}^{3} \sim 1800 \mathrm{~g} \text {. }
$$

A water balance around sludge storage can be performed to calculate the initial (starting state) free water:

$$
\begin{aligned}
& \text { Initial free water }+ \text { interstitial water }=\text { end-state water }+ \text { water consumed. } \\
& \text { Water consumed }=49.1 \mathrm{~g} \mathrm{H}_{2} \mathrm{O}+218 \mathrm{~g} \mathrm{H}_{2} \mathrm{O}=267.1 \mathrm{~g} \mathrm{H}_{2} \mathrm{O} \sim 267 \mathrm{~g} \\
& \text { Initial free water }=1800 \mathrm{~g}+267 \mathrm{~g}-650 \mathrm{~g}=1417 \mathrm{~g} \sim 1420 \mathrm{~cm}^{3} .
\end{aligned}
$$


The initial starting-state volume of sludge plus free water $=$

$$
\left.1000 \mathrm{~cm}^{3}(\mathrm{KW} \text { canister sludge })+1420 \mathrm{~cm}^{3} \text { (initial free water }\right)=2420 \mathrm{~cm}^{3} \text {. }
$$

Therefore, during storage, the total volume occupied in the container, starting with initial $\mathrm{KW}$ canister sludge + free water, is expected to contract by $20 \mathrm{~cm}^{3}\left(2420 \mathrm{~cm}^{3}-2400 \mathrm{~cm}^{3}\right)$, or $0.83 \%$.

These calculations do not consider water losses from the container by evaporation.

\section{References}

Pearce, K. L. 2002. Spent Nuclear Fuel Project Technical Databook, Volume 2, Sludge. HNF-SD-SNF-TI-015, Rev. 9, Vol. 2, Fluor Hanford, Richland, WA.

Plys, M. G., and K. L. Pearce. 2001. Supporting Basis for Spent Nuclear Fuel Project Sludge Technical Databook. SNF-7765, Rev. 0, EDT 629145, Fluor Hanford, Richland, WA.

Plys, M. G., and K. L. Pearce. 2002. Supporting Basis for Spent Nuclear Fuel Project Sludge Technical Databook. SNF-7765, Rev. 1, Fluor Hanford, Richland, WA.

Schmidt, A. J., and C. H. Delegard. 2002. Assessment of K Basin Sludge Volume Expansion Resulting from Uranium Corrosion During Storage. PNNL-13786, Pacific Northwest National Laboratory, Richland, WA. 